\title{
Indoleamine 2,3-dioxygenase 1 (IDO1) activity correlates with immune system abnormalities in multiple myeloma
}

Giuseppina Bonanno ${ }^{1}$, Andrea Mariotti ${ }^{1}$, Annabella Procoli ${ }^{1}$, Valentina Folgiero ${ }^{2}$, Daniela Natale ${ }^{1}$, Luca De Rosa $^{3}$, Ignazio Majolino ${ }^{3}$, Linda Novarese ${ }^{4}$, Alberto Rocci ${ }^{5}$, Manuela Gambella ${ }^{5}$, Marilena Ciciarello ${ }^{6}$, Giovanni Scambia ${ }^{1}$, Antonio Palumbo ${ }^{5}$, Franco Locatelli, ${ }^{2,7}$, Raimondo De Cristofaro ${ }^{4}$ and Sergio Rutella ${ }^{2^{*}}$

\begin{abstract}
Background: Multiple myeloma (MM) is a plasma cell malignancy with a multifaceted immune dysfunction. Indoleamine 2,3-dioxygenase 1 (IDO1) degrades tryptophan into kynurenine (KYN), which inhibits effector T cells and promote regulatory T-cell (Treg) differentiation. It is presently unknown whether MM cells express IDO1 and whether IDO1 activity correlates with immune system impairment.

Methods: We investigated IDO1 expression in 25 consecutive patients with symptomatic MM and in 7 patients with either monoclonal gammopathy of unknown significance (MGUS; $n=3$ ) or smoldering MM (SMM; $n=4)$. IDO1-driven tryptophan breakdown was correlated with the release of hepatocyte growth factor (HGF) and with the frequency of Treg cells and NY-ESO-1-specific CD8 ${ }^{+} \mathrm{T}$ cells.

Results: KYN was increased in 75\% of patients with symptomatic MM and correlated with the expansion of CD4 ${ }^{+} \mathrm{CD}_{25}{ }^{+}$FoxP3 ${ }^{+}$Treg cells and the contraction of NY-ESO-1-specific CD8 ${ }^{+} \mathrm{T}$ cells. In vitro, primary MM cells promoted the differentiation of allogeneic $\mathrm{CD} 4^{+} \mathrm{T}$ cells into bona fide $\mathrm{CD} 4^{+} \mathrm{CD} 25^{\text {hi }} \mathrm{FoxP} 3^{\text {hi }}$ Treg cells and suppressed IFN- $\mathrm{Y} / \mathrm{LL}-2$ secretion, while preserving IL-4 and IL-10 production. Both Treg expansion and inhibition of Th1 differentiation by MM cells were reverted, at least in part, by D,L-1-methyl-tryptophan, a chemical inhibitor of IDO. Notably, HGF levels were higher within the BM microenvironment of patients with $\mathrm{IDO}^{+}$myeloma disease compared with patients having IDO- MM. Mechanistically, the antagonism of MET receptor for HGF with SU11274, a MET inhibitor, prevented HGF-induced AKT phosphorylation in MM cells and translated into reduced IDO protein levels and functional activity.
\end{abstract}

Conclusions: These data suggest that IDO1 expression may contribute to immune suppression in patients with MM and possibly other HGF-producing cancers.

\section{Background}

The establishment of anti-tumor immunity requires the interaction of different cell types including, among others, APC and T cells. Escape from immunosurveillance through immunoselection, also known as immunoediting, and immunosubversion, i.e., active suppression of the immune response, is a hallmark of cancer [1]. In this respect, naturally occurring $\mathrm{CD}^{+}{ }^{+} \mathrm{FoxP}^{+}$regulatory

\footnotetext{
*Correspondence: sergio.rutella@opbg.net

${ }^{2}$ Department of Pediatric Hematology/Oncology, IRCCS Bambino Gesù

Children's Hospital, Rome, Italy

Full list of author information is available at the end of the article
}

T cells (Treg), a T-cell subset frequently over-represented in cancer-bearing hosts, were shown to suppress tumorassociated antigen (TAA)-reactive T cells, both in vitro [2] and in vivo [3]. Indoleamine 2,3-dioxygenase 1 (IDO1) is a tryptophan-catabolizing enzyme encoded by the IDOI gene. IDO1 oxidizes tryptophan into $\mathrm{N}$-formylkynurenine, which is rapidly converted to kynurenine (KYN) by the action of KYN formamidase [4]. The same reaction can be catalyzed by tryptophan 2,3-dioxygenase (TDO), a heme-containing cytosolic enzyme encoded by TDO2 gene and detected at high levels in the liver [5]. In humans, IDO1 is expressed by a unique subset of

\section{Biomed Central}


dendritic cells (DC) [6], by acute myeloid leukemia $[7,8]$ and by a variety of solid tumors, such as colorectal cancer [9], melanoma [10] and serous ovarian cancer [11]. The IDO1-driven production of KYN promotes the development, stabilization and activation of Treg cells, while suppressing effector $\mathrm{T}$ cells, all of which may contribute to immune system impairment in cancer-bearing individuals [12]. Recently, a mechanism of tumoral immune resistance centered on tryptophan degradation by TDO has been described in human tumors, such as melanoma, hepatocarcinoma, glioma and bladder carcinoma, but not in leukemia or lymphoma [13,14]. Multiple myeloma (MM) is a malignant plasma cell (PC) disorder, accounting for approximately $1 \%$ of neoplastic diseases and $13 \%$ of hematological cancers [15], and evolving from a monoclonal gammopathy of undetermined significance (MGUS) that progresses to smoldering myeloma (SMM) and, finally, to symptomatic MM. In recent years, the introduction of autologous hematopoietic stem cell transplantation (HSCT) and the availability of novel drugs such as thalidomide, lenalidomide and bortezomib, have prolonged overall survival [16,17]. Importantly, MM tumor cells are susceptible to immune recognition in the form of graft-versus-myeloma effect, as suggested by the therapeutic efficacy of allogeneic HSCT. Indeed, in 162 cases of newly diagnosed MM, event-free and overall survival were improved in patients given autologousallogeneic HSCT (tandem transplantation) as compared with patients lacking an HLA-matched sibling donor and receiving double autologous HSCT [18].

MM is unique in its ability to elude immunosurveillance, as a result of qualitative and/or quantitative abnormalities of DC and Treg cells [19], and of enhanced release of immunoregulatory cytokines by microenvironmental cells [20]. For instance, interaction between myeloma cells and plasmacytoid DC in MM bone marrow (BM) triggers the release of known MM-cell growth factors, including IL-10, IL-6, and MCP-1 or IP10 [21]. Furthermore, BM stromal cells (BMSC) in MM secrete immunomodulatory and pro-angiogenic molecules, such as TGF- $\beta$, vascular endothelial growth factor, IL-6 and hepatocyte growth factor (HGF) [22,23]. HGF is a 90-kd protein that signals through the MET receptor and is endowed with previously unappreciated effects on the immune response, as shown both in vitro and in vivo $[24,25]$. HGF confers tolerogenic functions to human, monocyte-derived (Mo)-DC by up-regulating IDO1 expression and IL-10 secretion [26]. Several MM cell lines both release and activate HGF by secreting HGFactivator (HGFA), a factor XIIa-related serine protease [27]. Importantly, high levels of HGF in serum and BM fluid of patients with MM predict a dismal prognosis, with a survival time of 32 and 21 months for patients with low and high HGF, respectively [23,28]. HGF values have been reported to decline after treatment with highdose chemotherapy in patients with MM who obtain at least a partial response [29]. The expression and function of IDO1 in MM have not been investigated previously. We provide evidence that KYN are increased in the peripheral blood $(\mathrm{PB})$ and $\mathrm{BM}$ of patients with $\mathrm{MM}$, in correlation with HGF release, expansion of Treg cells and shrinkage of NY-ESO-1-specific $\mathrm{CD}^{+} \mathrm{T}$ cells. In vitro, HGF antagonism with SU11274, a chemical inhibitor of MET, translated into the down-regulation of IDO protein and functional activity in MM cells.

\section{Methods}

\section{Abs and reagents}

The following tumor cell lines were obtained from American Type Culture Collection (ATCC; LGC Standards, Milan, Italy): U266, MOLP-8, RPMI-8226 (human MM) and U87-MG (human glioma). Primary rat hepatocytes were a generous gift of Anna Alisi (OPBG, Rome). CD138 Microbeads, Human $\mathrm{CD}^{+} \mathrm{CD} 25^{+}$Regulatory T-Cell Isolation Kit, Monocyte Isolation Kit II, Treg Suppression Inspector, Mo-DC Differentiation Medium, Mo-DC Maturation Medium and anti-CD166 (ALCAM or activated leukocyte cell adhesion molecule) mAb (3A6 clone) were purchased from Miltenyi Biotec (Bergisch Gladbach, Germany). Anti-human IDO antibodies (clone 700838), recombinant human IFN- $\gamma$, IL-2 and HGF, as well as ELISA kits for the quantification of IL-10, TGF- $\beta 1$, IFN- $\gamma$ and HGF, were all purchased from R\&D Systems (Oxon, Cambridge, UK). The IDO chemical inhibitor D,L-1MT, a racemic mixture containing both the levo and the dextro isomer of 1MT, L-tryptophan, KYN, PMA and ionomycin were obtained from Sigma Chemicals (St. Louis, MO). 6-Fluoro-3[(1E)-2-(3-pyridinyl)ethenyl]-1H-indole (680C91), a selective and potent TDO inhibitor (Tocris Bioscience; Bristol, UK) was used at $5 \mu \mathrm{M}$ final concentration [5,14]. STAT3 Inhibitor III (WP1066) was purchased from Santa Cruz Biotechnology (Milan, Italy). The Human FoxP3 Staining Set was purchased from eBioscience (San Diego, CA). FITC-conjugated anti-CD8, FITC-conjugated anti-HLAA2, PerCP-conjugated anti-CD19 mAb, PE-conjugated anti-IL-2 mAb, anti-IL-4 and IL-10 mAb, FITCconjugated anti-IFN- $\gamma$ and anti-IL-17 mAb, FITCconjugated anti-CD14 mAb, PE-conjugated anti-CD1a $\mathrm{mAb}$, Cytofix/Cytoperm ${ }^{\mathrm{Tm}}$ solution and Golgi Plug Protein Transport Inhibitor ${ }^{\text {Thx }}$ were purchased from BD Biosciences (Mountain View, CA). PE-labeled NY-ESO$1_{157-165}$ pentamers (peptide sequence: SLLMWITQV) and PE-labeled influenza $A_{58-66}$ pentamers (peptide sequence: GILGFVFTL) were obtained from Pro Immune (Oxford, UK). Rabbit anti-human antibodies to Akt (pan) (C67E7) and phosphorylated Akt (Ser473) (D9E) 
were purchased from Cell Signaling Technology (Milan, Italy). Rabbit anti-human IDO (H-101 clone) and antiTDO2 antibodies (N1C1 clone) were purchased from Santa Cruz Biotechnology and from GeneTex (Irvine, CA), respectively. Mouse anti-human NY-ESO-1 antibodies were obtained from Life Technologies (Milan, Italy). The Cell Fixation and Permeabilization Kit was obtained from Invitrogen (Milan, Italy). Mouse antihuman GAPDH antibodies were from Millipore (Milan, Italy). Isotypic control Abs were purchased from BD Biosciences and eBioscience, as appropriate. SU11274, a selective MET inhibitor [30], was purchased from Calbiochem (La Jolla, CA).

\section{Patients' characteristics}

Twenty-five consecutive patients with $\mathrm{MM}$ and 7 patients with either MGUS $(n=3)$ or SMM $(n=4)$ participated into the study (Table 1), which was approved by the local Ethical Committee (protocol \#P/53/CE/2010). Surplus diagnostic material, i.e., PB and BM samples collected on Hospital admission (disease onset) or during follow-up visits, was used for the cellular and molecular studies detailed below, after obtaining patients' informed consent. The International Staging System (ISS) was used to classify myeloma disease [31]. Patients with ISS stages II and III were grouped together in the analysis, as they are considered to have higher-risk disease [32].

\section{Cell and serum preparation}

$\mathrm{PB}$ and $\mathrm{BM}$ samples collected at simultaneous timepoints were used to isolate PBMC and BMMC by density gradient centrifugation on Ficoll-Hypaque (Uppsala, Sweden). Cells were either used fresh or were stored in FCS with $10 \%$ dimethyl sulfoxide in the vapor phase of liquid nitrogen until the day of experimental manipulation. Sera obtained by centrifugation of clotted PB and BM samples at $400 \mathrm{~g}$ for 20 minutes were rapidly frozen and stored at $-80^{\circ} \mathrm{C}$ until analysis. Primary MM cells were purified by positive selection with CD138 microbeads, according to the manufacturer's instructions. Blood samples were also obtained by consented age- and sexmatched healthy blood donors and were used for the measurement of KYN, tryptophan and HGF as well as for the enumeration of FoxP3-expressing Treg cells.

\section{Expansion of BMSC}

BMMC were cultured in RPMI 1640 supplemented with 20\% FCS to establish BMSC [33]. The percentage of BMSC was evaluated after labeling with an anti-CD166 $\mathrm{mAb}$. After 3 weeks in culture, BMSC were either challenged with $100 \mathrm{IU} / \mathrm{ml} \mathrm{IFN}-\gamma$ for 24 hours or were left untreated. Culture supernatants were collected at baseline and after IFN- $\gamma$ provision to measure tryptophan levels and KYN production, as will be detailed.

\section{Mixed tumor-cell lymphocyte cultures (MTLC)}

$\mathrm{CD}_{25}{ }^{+}$cells were positively selected from buffy-coat preparations of consenting blood donors with directly conjugated anti-CD25 magnetic microbeads $\left(4 \mu \mathrm{l}\right.$ per $10^{7}$ cells) [26]. The remaining non-CD $25^{+}$fraction was used to isolate $\mathrm{CD} 4^{+} \mathrm{CD} 25^{-}$cells by positive selection with anti-CD4 mAb-coated microbeads. Primary MM cells were cultured under serum-free conditions (10\% BIT HCC-9500; Stem Cell Technologies, Vancouver, BC) with allogeneic $\mathrm{CD}^{+} \mathrm{T}$ cells in RPMI 1640 medium [26,34]. After 6 days, cells were harvested to evaluate cytokine secretion and expression of Treg-associated markers. In selected wells, IL-2 was provided to the MTLC at $10 \mathrm{IU} / \mathrm{ml}$. The IDO chemical inhibitor D,L$1 \mathrm{MT}$ was used at $200 \mu \mathrm{M}$ to assess the role of IDO1 in the conversion of Treg cells by MM cells.

\section{Cell proliferation tracking}

Freshly isolated $\mathrm{CD}^{+} \mathrm{T}$ cells were labeled with CFSE (2.5 $\mu \mathrm{M}$; Molecular Probes, Eugene, OR) for 10 minutes at room temperature. After washings in PBS supplemented with 3\% FCS, cells were used for co-culture experiments. The analysis of CFSE dilution in the proliferating cell progeny was pursued with the Mod Fit ${ }^{\circledR}$ LT 2.0 software (Verity Software House Inc., Topsham, ME) [35].

\section{Treg suppression assays}

Treg cells emerging from the MTLC were purified as above described and were co-cultured with allogeneic $\mathrm{CD} 4{ }^{+} \mathrm{CD} 25^{-}$responder $\mathrm{T}$ cells that were pre-loaded with CFSE. T-cell proliferation was induced with an optimized polyclonal stimulus, consisting of anti-CD2+antiCD3+anti-CD28 mAb.

\section{Quantification of Treg cells and NY-ESO-1-specific CD8 ${ }^{+} \mathrm{T}$ cells by flow cytometry}

The percentage of $\mathrm{CD}^{+} \mathrm{CD}_{2} 5^{+} \mathrm{FoxP}^{+}$Treg cells was estimated as previously published [26]. Appropriate fluorochrome-conjugated, isotype-matched mAb helped establish background fluorescence. Treg cells were identified and counted as $\mathrm{CD} 4^{+} \mathrm{CD} 25^{+} \mathrm{FoxP}^{+} \mathrm{T}$ cells within the $\mathrm{CD}^{+}{ }^{+} \mathrm{T}$-cell gate. To estimate the frequency of NYESO-1-specific and influenza-specific $\mathrm{CD}^{+} \mathrm{T}$ cells, PBMC from HLA-A2 ${ }^{+} \mathrm{MM}$ patients were first stained with either NY-ESO-1 $157-165$ pentamers or influenza $A_{58-}$ 66 pentamers for 15 minutes at room temperature and then with anti-CD8 and anti-CD19 mAb. After washings with PBS-BSA, the percentage of pentamer-positive cells was calculated after gating on CD19- lymphoid cells on a two-color CD8 vs. pentamer plot, to exclude from the 
Table 1 Patients' characteristics

\begin{tabular}{|c|c|c|c|c|c|c|c|}
\hline UPN & Diagnosis & Disease status & Light chain isotype & Cytogenetics & ISS stage & Therapy at sampling & Clinical status* \\
\hline 1 & $\mathrm{MM}$ & Relapse & $\operatorname{lgG} \mathrm{K}$ & Normal & III & PDN, Cy & Deceased \\
\hline 2 & SMM & Onset & $\lg G \lambda$ & $\mathrm{t}(4 ; 14)$ & N.A. & None & Alive/SMM \\
\hline 3 & $\mathrm{MM}$ & Stable disease & Non secretory & Normal & 1 & None & Alive/PR \\
\hline 4 & SMM & Onset & $\lg A K$ & Normal & N.A. & None & Alive/SMM \\
\hline 5 & $\mathrm{MM}$ & Partial response & $\lg G \mathrm{~K}$ & Normal & I & PDN, Thalidomide & Alive/PR \\
\hline 6 & $\mathrm{MM}$ & Onset & $\lg G \mathrm{k}$ & $\operatorname{Del}(13 q) ; t(4 ; 14)$ & 1 & None & Deceased \\
\hline 7 & MM & Onset & $\lg A \lambda$ & Normal & III & None & Lost at follow-up \\
\hline 8 & $\mathrm{MM}$ & Onset & $\lg G \lambda$ & $\operatorname{Del}(13 q)$ & 1 & None & Alive/PR \\
\hline 9 & $\mathrm{MM}$ & Onset & $\lg D \lambda$ & $\operatorname{Del}(13 q)$ & 1 & VMPT & Alive/CR \\
\hline 10 & MGUS & - & Micromolecular, $\lambda$ & Normal & N.A. & None & Alive/MGUS \\
\hline 11 & $\mathrm{MM}$ & Onset & Micromolecular, $\mathrm{k}$ & Normal & 1 & Prednisone & Alive/Stable disease \\
\hline 12 & MGUS & - & $\lg G \mathrm{~K}$ & Normal & N.A. & None & Alive/MGUS \\
\hline 13 & MM & Onset & Micromolecular, $\mathrm{k}$ & Normal & III & Auto-HSCT & Alive/CR \\
\hline 14 & MM & Relapse & $\lg A K$ & $\operatorname{Del}(13 q)$ & 1 & Prednisone & Alive/PD \\
\hline 15 & $\mathrm{MM}$ & Onset & NA & Normal & ॥ & None & NA \\
\hline 16 & $\mathrm{MM}$ & Partial response & $\lg G \lambda$ & Normal & III & PDN & Alive/Stable disease \\
\hline 17 & MM & Relapse & $\lg A \lambda$ & Normal & III & PDN & Alive/PR \\
\hline 18 & SMM & Onset & $\lg A K$ & Normal & N.A. & None & Alive/progressed to MM \\
\hline 19 & $\mathrm{MM}$ & Relapse & $\lg A K$ & p53 mutation & $\|$ & None & Alive/PR \\
\hline 20 & $\mathrm{MM}$ & Stable disease & $\lg G \mathrm{~K}$ & Normal & 1 & MP & Deceased \\
\hline 21 & SMM & Onset & $\lg G \lambda$ & Normal & N.A. & None & Alive/SMM \\
\hline 22 & MGUS & - & $\lg G \mathrm{~K}$ & Normal & N.A. & None & Alive/MGUS \\
\hline 23 & $\mathrm{MM}$ & Onset & $\lg G \mathrm{~K}$ & $\mathrm{t}(11 ; 14) ; 14 \mathrm{q} 32$ translocation & I & None & Alive \\
\hline 24 & $\mathrm{MM}$ & Onset & $\lg G \mathrm{~K}$ & $\operatorname{Del}(13 q) ;$ del(17p) & $\|$ & None & Alive \\
\hline 25 & $\mathrm{MM}$ & Relapse & $\lg A$ & $\operatorname{Del}(13 q) ; t(4: 14)$ & II & None & Alive, relapse \\
\hline 26 & $\mathrm{MM}$ & Onset & Micromolecular, $\lambda$ & ND & III & None & Alive/PR \\
\hline 27 & $\mathrm{MM}$ & Relapse & Non secretory & ND & I & None & Alive/NGPR \\
\hline 28 & $\mathrm{MM}$ & Relapse & $\lg A \lambda$ & Normal & I & None & Alive/NGPR \\
\hline 29 & $\mathrm{MM}$ & Onset & $\lg A K$ & Del(13q); del(17p) & III & None & Alive/PD \\
\hline 30 & $\mathrm{MM}$ & Onset & $\lg A \lambda$ & $\operatorname{Del}(13 q) ; t(4: 14)$ & I & None & Alive/PR \\
\hline 31 & $\mathrm{MM}$ & Relapse & $\lg G \mathrm{~K}$ & ND & I & Prednisone & Alive/PD \\
\hline 32 & MM & Relapse & $\lg G \mathrm{~K}$ & ND & I & None & Alive/PR \\
\hline
\end{tabular}

Patients' characteristics. Patients' demographics, disease features, medical therapies and disease status at sampling are shown. Abbreviations: $S M M$ smoldering multiple myeloma, $C R$ complete remission, $P R$ partial remission, $P D$ progressive disease, $V G P R$ very good partial response, NA not applicable, $N D$ not done, $B J$ Bence-Jones proteinuria. PDN prednisone, Cy cyclophosphamide, MP melphalan + prednisone, VMPT bortezomib, melphalan, prednisone and thalidomide *12 months after inclusion in the study.

analysis all events that could be ascribed to non-specific binding of the pentamers to B cells.

\section{Cytokine assays}

Cytokine production at the single-cell level was assessed with mAb directed against IL-2, IL-4, IL-10, IL-17A and IFN- $\gamma$. CD4 ${ }^{+}$cells were activated for 5 hours with $50 \mathrm{ng} /$ $\mathrm{ml}$ PMA and $1 \mu \mathrm{g} / \mathrm{ml}$ ionomycin, in the presence of inhibitors of protein transport. For IL-10 detection, $\mathrm{CD} 4^{+}$cells were stimulated with LPS $(1 \mu \mathrm{g} / \mathrm{ml})$ for 24 hours, washed, fixed, permeabilized and then stained with pre-titrated amounts of cytokine-specific antibodies. Cytokine levels in patients' serum or in culture supernatants were quantitated with commercially available ELISA. The limits of detection were as follows: $1 \mathrm{pg} / \mathrm{ml} \mathrm{IL-10;} 7 \mathrm{pg} / \mathrm{ml}$ TGF- $\beta 1,15.6 \mathrm{pg} / \mathrm{ml}$ IFN- $\gamma$, and $40 \mathrm{pg} / \mathrm{ml}$ HGF.

\section{Western blotting}

Primary $\mathrm{CD}_{138^{+}}$cells or MM cell lines $\left(6 \times 10^{5}\right)$ were centrifuged at 1,200 rpm for 10 minutes and cell pellets were lysed with RIPA buffer $[150 \mathrm{mM} \mathrm{NaCl}, 1 \% \mathrm{NP}-40$, $0,5 \%$ sodium deoxycholate, $0,1 \% \mathrm{SDS}, 50 \mathrm{mM}$ Tris- $\mathrm{HCl}$ (pH=8), $1 \mathrm{mM}$ PMSF, $1 \mathrm{mM}$ EGTA, $50 \mathrm{mM}$ NaF, 50 $\mathrm{mM} \mathrm{Na} \mathrm{NO}_{4}$ and protease inhibitors (Roche, Milan, Italy)]. Cell lysates were incubated on ice for 20 minutes and clarified by centrifugation at $14,000 \mathrm{rpm}$ for 
20 minutes. Cell extracts obtained with RIPA buffer were boiled for 5 minutes at $95^{\circ} \mathrm{C}$ and analyzed by $12 \%$ SDSPAGE. Samples were transferred onto nitrocellulose membrane (Bio-Rad, Milan, Italy). Blots were probed with primary antibodies at 1:1000 dillution, washed and developed with horseradish peroxidase-conjugated rabbit or mouse secondary antibodies (Bio-Rad), as appropriate. The bands were quantified densitometrically using the ImageJ software (National Institutes of Health, Bethesda, MD).

\section{Real-time quantitative PCR}

Total RNA was obtained from cultured MM cells using the RNeasy plus kit (Qiagen, Milan, Italy) according to manufacturer's instructions. Complementary DNA (cDNA) was prepared starting from $1 \mu \mathrm{g}$ of total RNA using the iScript cDNA Synthesis Kit (Bio-Rad) according to the manufacturer's instructions. Amplifications were carried out using specific primers (IDO1 gene: forward primer 5' $\rightarrow$ 3': GGGACACTTTGCTAAAGGCG; reverse primer 5' $\rightarrow$ 3': GTCTGATAGCTGGGGGTTGC) and the iQ SYBRGreen Supermix (Bio-Rad) in a final volume of $25 \mu \mathrm{L}$, starting with a 3-min template denaturation step at $95^{\circ} \mathrm{C}$ followed by 40 cycles of $15 \mathrm{~s}$ at $95^{\circ} \mathrm{C}$ and $1 \mathrm{~min}$ at $60^{\circ} \mathrm{C}$. $\beta$-actin was used as housekeeping gene (forward primer $5^{\prime} \rightarrow 3^{\prime}$ : GCCGACAGGATG CAGAAGGAG; reverse primer 5' $\rightarrow$ 3': CAGGATGGA GCCGCCGATC). Standard curves were generated using a serial dilution of the initial amount of control cDNA to determine the range of template concentrations, and showed a good linearity and efficiency for the different reactions. Melt curves of the reaction products were also generated to assess the specificity of the measured fluorescence. Samples were run in triplicate and the mean of threshold cycles $(\mathrm{Ct})$ for each specimen was used to obtain the fold-change of gene expression level, using the following equation: fold change $=2-(\mathrm{Ct})$, where $\mathrm{Ct}=$ $\mathrm{Ct}$ specific gene-Ct $\beta$-actin, and $(\mathrm{Ct})=\mathrm{Ct}$ specimen-Ct control. Calculations were made with the RelQuant Excel spreadsheet (Bio-Rad).

\section{Differentiation of Mo-DC}

Circulating monocytes were isolated with CD14 Microbeads, as already published [33]. Monocytes were routinely $>97 \%$ pure, as evaluated by FACS analysis. Cells were cultured for 7 days in GM-CSF/IL-4-containing medium, followed by 3 days of maturation in TNF$\alpha$-containing medium.

\section{Immunofluorescence analysis}

Labeled cells were run through a FACS Canto ${ }^{\circledR}$ flow cytometer (BD Biosciences) with standard equipment. A minimum of 20,000 events was collected and acquired in list mode using the FACS Diva ${ }^{\circledR}$ software package (BD Biosciences).

\section{ID01 activity}

Tryptophan and KYN levels were measured with reverse-phase HPLC. Briefly, sample aliquots were deproteinized with $0.3 \mathrm{M} \mathrm{HClO}_{4}$. Supernatants were spiked with $50 \mu \mathrm{M}$ 3-L-nitrotyrosine and analyzed using a ReproSil-Pur C18-AQ RP-HPLC column (Dr. Maisch $\mathrm{GmbH}$, Ammerbuch-Entringen, Germany), using a double-pump HPLC apparatus from Jasco (Tokyo, Japan) equipped with spectrophotometric and fluorescence detectors. The chromatographic peaks were detected by recording UV absorbance at $360 \mathrm{~nm}$ and emission fluorescence at $366 \mathrm{~nm}$, after excitation at $286 \mathrm{~nm}$. The elution solvent was as follows: $2.7 \% \mathrm{CH}_{3} \mathrm{CN}$ in $15 \mathrm{mM}$ acetate buffer, pH 4.00 (both HPLC-grade; Fluka, Milan, Italy). The Borwin 1.5 and MS Excel software packages were used for instrument set-up and peak quantification. The concentration of components was calculated according to peak heights and was compared with both 3-nitro-L-tyrosine as internal standard and with reference curves constructed with L-tryptophan and KYN.

\section{Statistical methods}

The approximation of data distribution to normality was tested preliminarily using statistics for kurtosis and symmetry. Data were presented as median and inter-quartile range and comparisons were performed with the MannWhitney $U$ test for paired or unpaired data, or with the Kruskal-Wallis test with Bonferroni's correction for multiple comparisons, as appropriate. The criterion for statistical significance was defined as a $p$ value $\leq 0.05$.

\section{Results}

\section{IDO1 is functional and is mainly expressed by the} malignant PC

In mice, most of the KYN formed through the action of IDO is pooled in both plasma and tissues [4]. Based on this observation, we measured tryptophan and KYN both in serum and in BM fluid collected from a cohort of 25 patients with newly diagnosed or relapsed MM, and in 7 patients with either SMM $(n=4)$ or MGUS $(n=3)$ as controls. In the overall population of patients with $\mathrm{PC}$ dyscrasia, KYN were higher both in the $\mathrm{PB}$ (2.92 $\mu \mathrm{M} / \mathrm{L}$, range $1.0-7.1)$ and in the $\mathrm{BM}(2.0 \mu \mathrm{M} / \mathrm{L}$, range $0.45-9.57)$ as compared with age/sex-matched healthy controls $(1.80 \mu \mathrm{M} / \mathrm{L}$, range $1.11-2.65$, and 1.5 $\mu \mathrm{M} / \mathrm{L}$, range $0.6-2.21$, in $\mathrm{PB}[p<0.0001]$ and $\mathrm{BM}$ $[p=0.0141]$, respectively), suggesting in vivo activation of IDO1. When MM patients were arbitrarily dichotomized based on serum KYN (lower or greater than the median in healthy controls, i.e., $1.8 \mu \mathrm{M}$ ), 19 out of 25 patients (75\%) could be assigned to the KYN ${ }^{\text {hi }}$ MM group. KYN 
levels were also augmented in the PB and BM of patients with MGUS and SMM and no statistically significant differences in KYN release were recorded when comparing these patient groups (data not shown). As the composite results in Figure $1 A$ clearly show, KYN were significantly more represented in the BM microenvironment of patients assigned to ISS stage II/III compared with those having less advanced disease. Furthermore, tryptophan concentrations both in $\mathrm{PB}$ and in $\mathrm{BM}$ were lower in MM patients with ISS stage II-III disease compared with MM patients with ISS stage I disease and with healthy controls (Figure $1 A$ ).

Malignant PC were magnetically isolated in $17 \mathrm{MM}$ patients with sufficient amounts of surplus diagnostic material, and the expression of IDO protein was investigated with Western blotting. As shown in Figure $1 B$, PC expressed readily detectable but varying levels of IDO in 12 out of $17 \mathrm{MM}$ patients when compared with U937 monocytic leukemia cells used as negative control. In 5 randomly selected MM samples, we also assessed the expression of IDO protein by flow cytometry in purified CD $138^{+} \mathrm{PC}$, which correlated with IDO levels as detected by WB. In all samples tested, $\mathrm{CD}^{+} \mathrm{T}$ cells stained negatively for IDO. One representative experiment is depicted in Figure $1 C$. We next asked whether cellular sources other than the malignant PC may account for IDO expression within the immune suppressive BM milieu. To accomplish this goal, we investigated IDO expression in patients' BMSC that were either activated with exogenous IFN- $\gamma$ for 24 hours or left

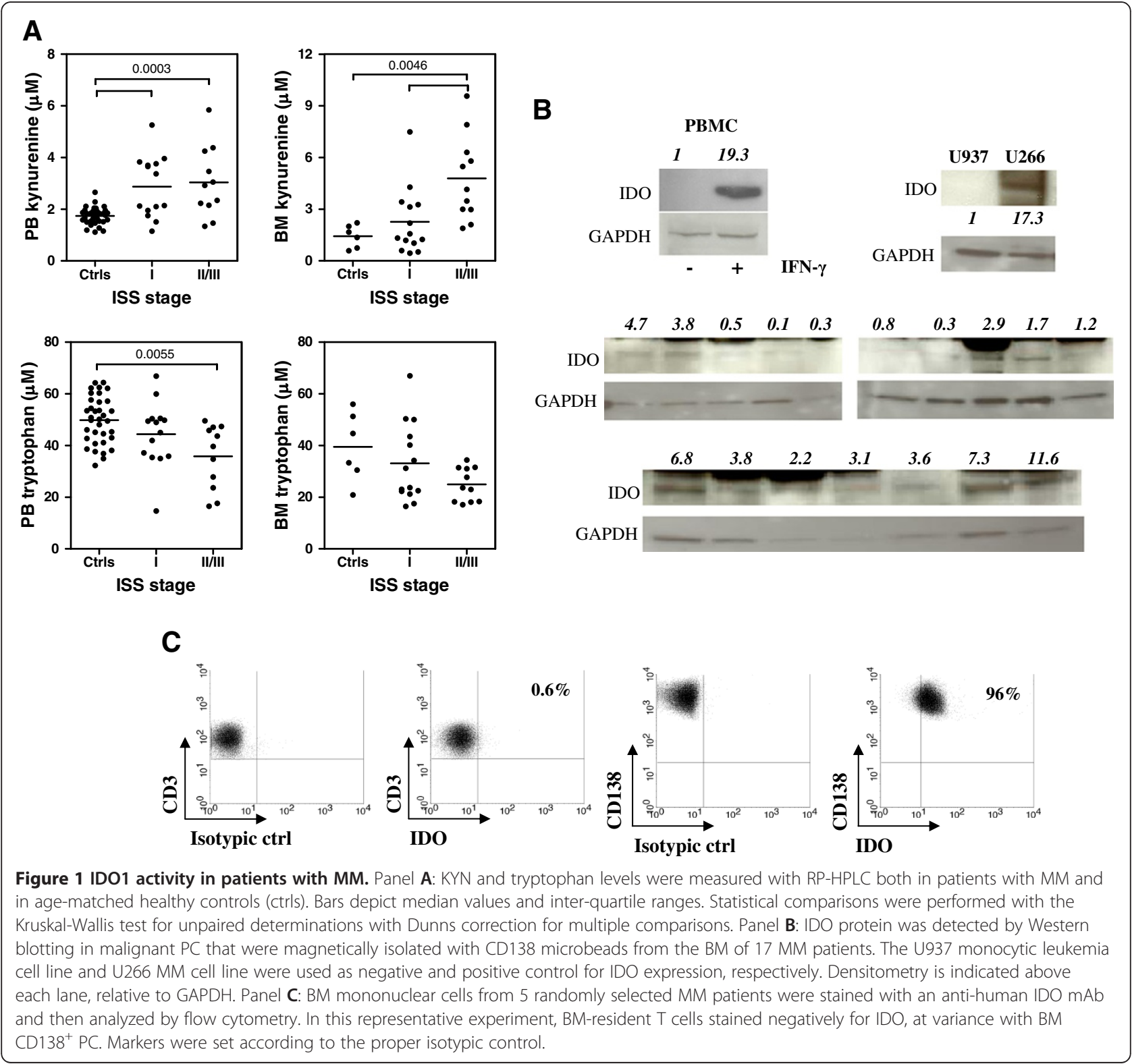


untreated. Skin fibroblasts from healthy individuals were used as a control mesenchymal cell type. As shown in Figure $2 A$, IFN- $\gamma$ challenge induced IDO protein in $\mathrm{CD}_{166^{+}}$BMSC from MM patients. KYN were not detected in unstimulated cultures (Figure $2 B$ ). Conversely, IFN- $\gamma$ induced robust KYN production by MM BMSC that was associated with tryptophan consumption (Figure $2 B$ ). It should be noted that both KYN release and tryptophan breakdown were lower in supernatants of IFN- $\gamma$-stimulated skin fibroblasts compared with $\mathrm{MM}$ BMSC, suggesting that the latter cell type may be particularly sensitive to IFN- $\gamma$ stimulation. The supernatants of IFN- $\gamma$-challenged MM BMSC were also transferred to an allogeneic MLR to determine whether IDO-driven tryptophan catabolites affect the acquisition of a Treg phenotype upon T-cell activation induced by alloantigens. As shown in Figure $2 C$, FoxP3 ${ }^{\text {lo }}$ and FoxP3 ${ }^{\text {hi }}$ cell populations were clearly distinguishable after flow cytometric analysis. The frequency of $\mathrm{CD} 4^{+} \mathrm{CD} 25^{+} \mathrm{FoxP} 3^{\text {low }} \mathrm{T}$ cells in the MLR cultures was significantly expanded irrespective of the presence of supernatants derived from MM BMSC and likely reflected T-cell activation in response to HLA- disparate stimulator cells. Interestingly, the provision of tryptophan-depleted and KYN-enriched supernatants from MM BMSC translated into a significant increase of $\mathrm{CD} 4^{+} \mathrm{CD} 25^{+}$FoxP $3{ }^{\text {hi }}$ Treg cells (Figure $2 \mathrm{C}$ ). The addition of excess tryptophan to the MLR did not limit the expansion of either FoxP3 ${ }^{\text {lo }}$ or FoxP3 ${ }^{\text {hi }}$ Treg cells (Figure $2 C$ ), suggesting that the increase of Treg cells in the cultures was not merely due to tryptophan starvation but rather it resulted from increased KYN production. Collectively, these data indicated that, in the absence of proinflammatory stimuli such as IFN- $\gamma$, BMSC are unlikely to account for IDO1 expression/activity in patients with MM. In line with this assumption, we were unable to detect IFN- $\gamma$ in the BM fluid of patients with MM (data not shown). A previous study also showed no constitutive IDO activity in BMSC from 5 patients with MM [36].

ID01 activity in MM correlates with the expansion of Treg cells and with the contraction of NY-ESO-1-specific CD8 ${ }^{+}$ T cells

We also asked whether IDO1 activity correlates with in vivo expansion of potentially immune-suppressive

\section{A}
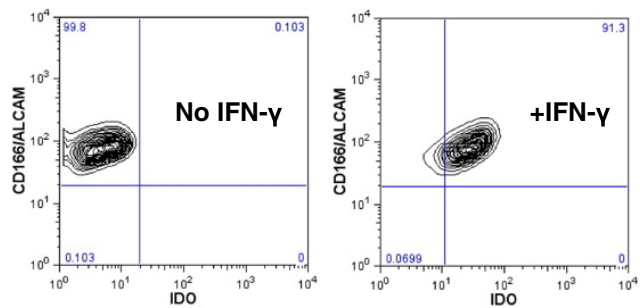

B
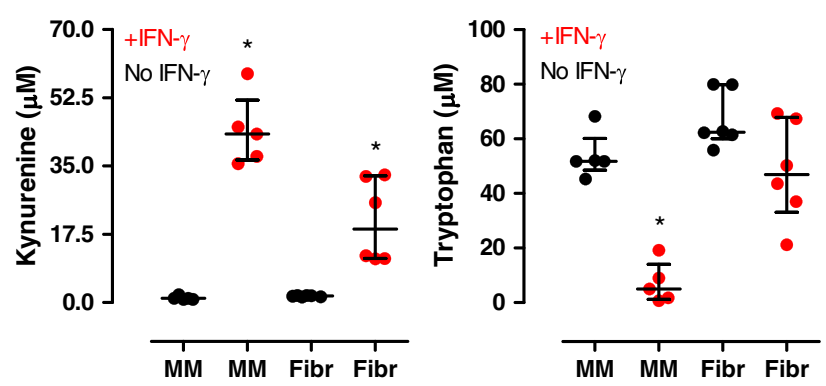
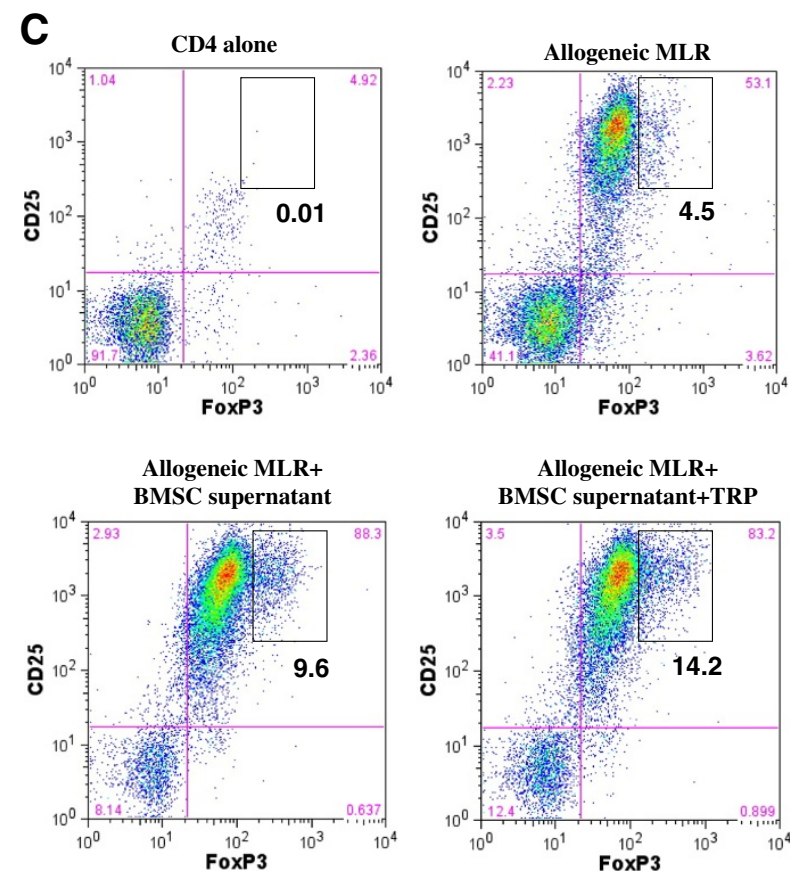

Figure 2 IDO1 activity in MM BMSC. Panel A: BMSC were generated as previously detailed [33] and were either left untreated or activated with $100 \mathrm{IU} / \mathrm{ml}$ IFN- $\gamma$ for 24 hours. BMSC were fixed, permeabilized and stained with anti-IDO and anti-CD166 mAb. One representative experiment out of 5 with similar results is shown. Panel B: BMSC from 5 representative patients with MM and skin fibroblasts from 6 healthy subjects were either left untreated (black dots) or activated with $100 \mathrm{IU} / \mathrm{ml}$ IFN- $\gamma$ for 24 hours (red dots) before measuring KYN and tryptophan level in culture supernatants. Comparisons between untreated and IFN- - -stimulated samples were performed with the Wilcoxon matched-paired signed rank test. ${ }^{*} p<0.01$ compared with untreated samples. Panel C: Supernatants of BMSC cultures were transferred (20\% V/v) to an MLR containing allogeneic naïve CD4 ${ }^{+}$T cells and third-party monocytes (at a fixed 1:3 ratio). IL-2 was provided to the cultures as a Treg growth factor. After 6 days, cells were harvested and labeled with anti-FoxP3 and anti-CD25 mAb to monitor the acquisition of a regulatory phenotype. A representative experiment out of 3 with similar results is shown. Markers were set according to the proper isotypic control (not shown). Rectangular gates were set to include CD4 ${ }^{+} \mathrm{CD} 25^{\text {hi }} \mathrm{FoxP} 3^{\text {hi }} \mathrm{T}$ cells. 
Treg cells. The gating strategy that we used to enumerate Treg cells in patients' $\mathrm{PB}$ and $\mathrm{BM}$ is illustrated in Additional file 1. As shown in Figure $3 A$, the frequency of bona fide Treg cells in the PB was significantly higher in patients with higher stage MM compared with patients with ISS stage I disease and with healthy controls. The increase of Treg cells also within BMMC of patients with ISS stage III disease (median 6.2\%, range 4.40-14.6) compared with stage II disease (median 9.3\%, range 4.6-14.1), stage I disease (median 4.15\%, range 1.0$7.6 \%$ ) and with healthy donors (median $3.1 \%$, range 2.3 4.0) suggested that Treg accumulation in the $M M$ microenvironment may be one additional mechanism through which anti-myeloma immunity is restrained. The frequency of circulating Treg cells was superimposable when comparing patients having MGUS or SMM with those suffering from symptomatic MM (data not shown).

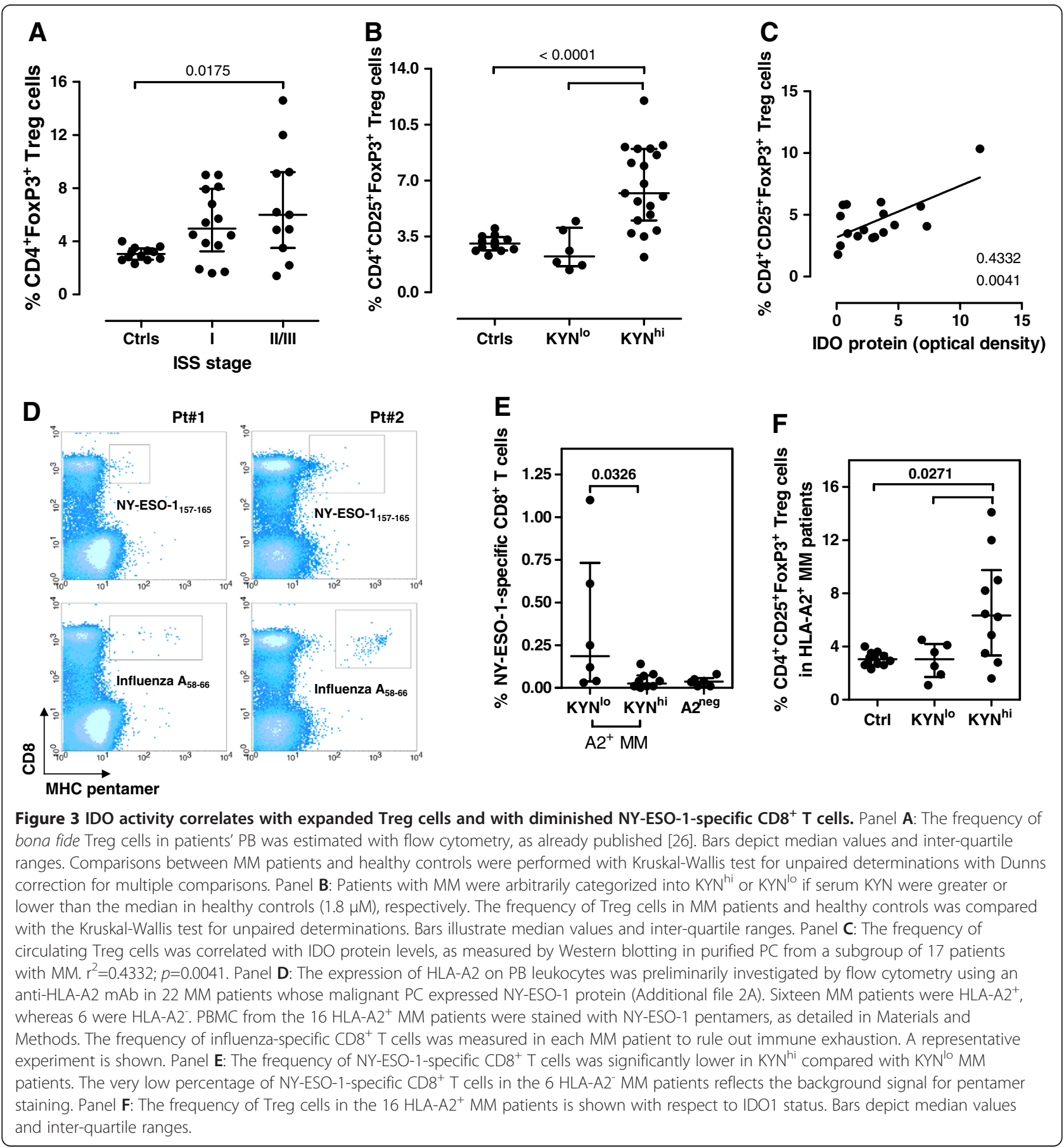


Interestingly, $\mathrm{CD} 4{ }^{+} \mathrm{CD} 25^{+} \mathrm{FoxP}^{+}$Treg cells were more abundant in the $\mathrm{PB}$ of $\mathrm{MM}$ patients with heightened KYN levels (Figure $3 B$ ). The frequency of Treg cells also correlated with IDO protein levels, as determined by Western blotting $\left(\mathrm{r}^{2}=0.4332, p=0.0041\right.$; Figure $\left.3 C\right)$. To get insights into the potential in vivo relevance of the above findings, we evaluated the frequency of myelomareactive, NY-ESO-1-specific $\mathrm{CD}^{+} \mathrm{T}$ cells in a subgroup of 16 HLA-A2 ${ }^{+} \mathrm{NY}-\mathrm{ESO}-1^{+} \mathrm{MM}$ patients, 10 of whom could be classified as $\mathrm{KYN}^{\text {hi }}$ based on serum $\mathrm{KYN}$ (Figure 1A). The expression of NY-ESO-1 was tested with Western blotting in this subgroup of patients and is shown in Additional file $2 A$. Additional six HLA-A2 MM patients served as negative control for pentamer staining. In the HLA-A2 $2^{+}$patients, the frequency of influenza-specific $\mathrm{CD}^{+} \mathrm{T}$ cells was measured together with that of NY-ESO-1-specific $\mathrm{CD}^{+} \mathrm{T}$ cells to rule out immune exhaustion (Figure $3 D$ ). Overall, compared with the $\mathrm{KYN}^{\text {lo }} \mathrm{MM}$ patients, HLA-A2 ${ }^{+} \mathrm{KYN}^{\text {hi }} \mathrm{MM}$ patients had fewer NY-ESO-1-specific $\mathrm{CD}^{+} \mathrm{T}$ cells (Figure $3 E$ ), but higher frequencies of Treg cells (Figure $3 F$ ), indicating that, at least in a subset of MM patients, IDO1 activity may impact on anti-myeloma immunity through effects that include both the expansion of Treg cells and the contraction of myeloma-specific effector $\mathrm{T}$ cells. As already shown in the whole cohort of $M M$ patients (Figure $3 A$ ), also in this subgroup of $10 \mathrm{KYN}^{\mathrm{hi}} \mathrm{HLA}_{-\mathrm{A} 2}{ }^{+}$ MM patients Treg cells were significantly more represented than in both $\mathrm{KYN}^{\mathrm{lo}} \mathrm{HLA}-\mathrm{A} 2^{+} \mathrm{MM}$ patients and healthy controls (Figure $3 F$ ).

\section{Myeloma cells lead to the differentiation of Treg cells in vitro through an IDO-dependent mechanism}

To test the hypothesis that IDO1-expressing myeloma cells sustain the amplification of Treg cells, allogeneic naïve $\mathrm{CD}^{+} \mathrm{T}$ cells were challenged in vitro with myeloma cells in a MTLC. The $\mathrm{CD}^{+} \mathrm{T}$ cells were preloaded with the fluorescent dye CFSE to track their proliferation. As evaluated through the combined staining with CFSE and anti-FoxP3 mAb (Figure $4 A-B$ ), IDO $^{+}$ myeloma cells induced an expansion of the overall Treg population. These effects were inhibited, albeit not completely, by the provision of D,L-1MT to the co-cultures. To assess whether proliferating myeloma cells competed for tryptophan, leading to its relative depletion independent of IDO, MM cells were loaded with CFSE and cultured for 72 hours to track cell proliferation. As shown in Additional file $2 B$, MM cells had minimal proliferative activity when maintained with complete medium in the absence of exogenous growth factors. The MM-induced Treg cells were capable of constraining the proliferation of allogeneic $\mathrm{CD} 4^{+} \mathrm{T}$ cells induced by polyclonal stimulation with a cocktail of anti-CD2/ $\mathrm{CD} 3 / \mathrm{CD} 28 \mathrm{mAb}$, indicating that they were functional
(Figure $4 C$ ). The $\mathrm{CD}^{+}{ }^{+} \mathrm{T}$ cells emerging from the MTLC were also activated with PMA and ionomycin and then assayed for intracellular cytokines assigned to the Th1, Th2 and Th17 lineage. A representative control experiment with commercially available Th1/Th2-polarized T cells is depicted in Additional file $3 A$. Figure $4 D$ shows the results of 3 experiments where IDO-expressing MM cells inhibited the development of IFN- $\gamma / \mathrm{IL}-2$-producing $\mathrm{T}$ cells in vitro. Conversely, IL-10, IL-17 and IL-4expressing $\mathrm{CD}^{+}{ }^{+} \mathrm{T}$ cells were unchanged after T-cell coculture with MM cells. Interestingly, D,L-1MT partially reverted the diminished T-cell expression of IFN- $\gamma$ and IL-2 in response to MM cells, and slightly increased IL-10 production at the single-cell level (Figure $4 D$ ). Figure $4 E$ illustrates a representative experiment aimed at measuring IL- 2 and IFN- $\gamma$ production under the different culture conditions here established.

\section{IDO1 activity in MM patients correlates with the release of HGF but not other immune-suppressive cytokines}

We next focused our studies on candidate cytokine stimuli that may be responsible for IDO1 induction in MM. In this respect, both TGF- $\beta$ and IL-10 are known to modulate IDO1 and may be expressed by the myeloma cells during progressive disease [37]. To this end, TGF- $\beta$ and IL-10 levels were measured in a subgroup of 19 MM patients (Additional file $3 B$ ). Although both IL-10 and TGF- $\beta$ were increased in some patients, both in the $\mathrm{PB}$ and BM, there was no correlation between IL-10/ TGF- $\beta$ release and serum KYN (data not shown). We subsequently quantitated HGF production both in $\mathrm{PB}$ and in BM fluid and showed that HGF was dramatically increased in patients with MM compared with those having MGUS or SMM, being particularly elevated in the immune-suppressive BM microenvironment (Figure $5 A-B$ ). Furthermore, HGF levels were higher in patients with ISS stage II/III disease compared with those having ISS stage I MM (Figure $5 C-D$ ), suggesting that the magnitude of HGF release reflects disease burden. Also, HGFA, whose presence is a pre-requisite for HGF activation in vivo [27], was higher in patients' $\mathrm{PB}$ and BM fluid compared with healthy controls (Figure $5 E$ ). When attempting to correlate HGF levels with KYN production, we found that HGF was higher in the BM microenvironment of patients with $\mathrm{KYN}^{\text {hi }} \mathrm{MM}$ compared with those having $\mathrm{KYN}^{\mathrm{lo}} \mathrm{MM}$ (Figure $5 F$ ). Also, serum HGF was not significantly different in the $\mathrm{KYN}^{\mathrm{lo}} \mathrm{MM}$ patients than in healthy controls. However, it should be emphasized that HGF levels overlapped in $\mathrm{KYN}^{\mathrm{lo}}$ patients and in a subgroup of 8 out of 19 (42\%) $\mathrm{KYN}^{\text {hi }}$ patients. Conversely, HGF levels were dramatically increased in the remaining $11 \mathrm{KYN}^{\text {hi }}$ patients when compared with $\mathrm{KYN}^{\mathrm{lo}} \mathrm{MM}$ and with healthy controls. As shown in Figure 5G, disease burden, HGF release as 


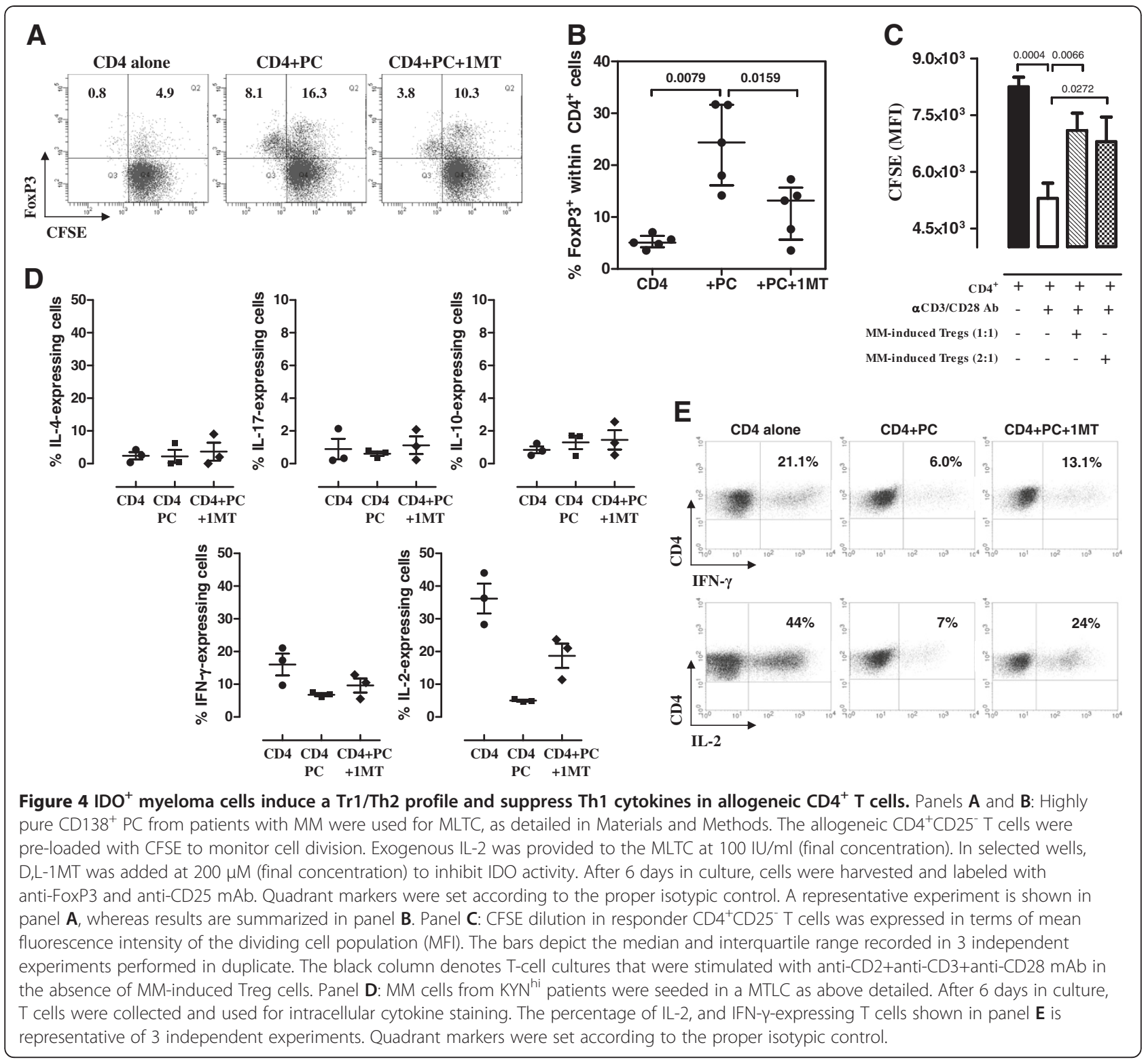

well as KYN and tryptophan levels were evaluated serially in 1 patient with MM, both before (disease onset) and after treatment ( $\mathrm{T} 1$ and $\mathrm{T} 2=6$ months and 1 year, respectively, after combination chemotherapy with bortezomib, melphalan and prednisone). The percentage of malignant $\mathrm{PC}$ and serum $\mathrm{M}$-component progressively declined in correlation with lowered HGF and KYN release. Moreover, the percentage of Treg cells diminished after treatment compared with baseline. Collectively, these data suggest that high HGF production in MM may correlate with IDO1 activity and with disease burden. Finally, we aimed at establishing a mechanistic link between HGF stimulation and IDO expression by MM cells. Preliminarily, we confirmed our previous findings that HGF potently induces IDO protein in mature,
CD14 ${ }^{-C D 1 a^{+}}$Mo-DC (Figure 6A-B) [26]. Prompted by technical limitations in the collection of high numbers of primary PC from MM patients, we treated U266 and MOLP-8 MM cells with exogenous HGF and then analyzed IDO expression at mRNA and protein level, as well as KYN release in culture supernatants [38]. As shown in Figure $6 C$, mRNA levels for IDO1 were unaffected by $\mathrm{HGF}$, at variance with those detected in IFN- $\gamma$ stimulated MM cells. Treatment with HGF resulted in enhanced phosphorylation of AKT, as well as increased IDO1 expression and enzyme activity in MOLP-8 cells (Figure 6D). Of interest, 1MT reverted the heightened KYN/tryptophan ratio measured in supernatants of HGF-stimulated MOLP-8 cells, indicating that KYN production could be ascribed to IDO1 activity (Figure 6E). 


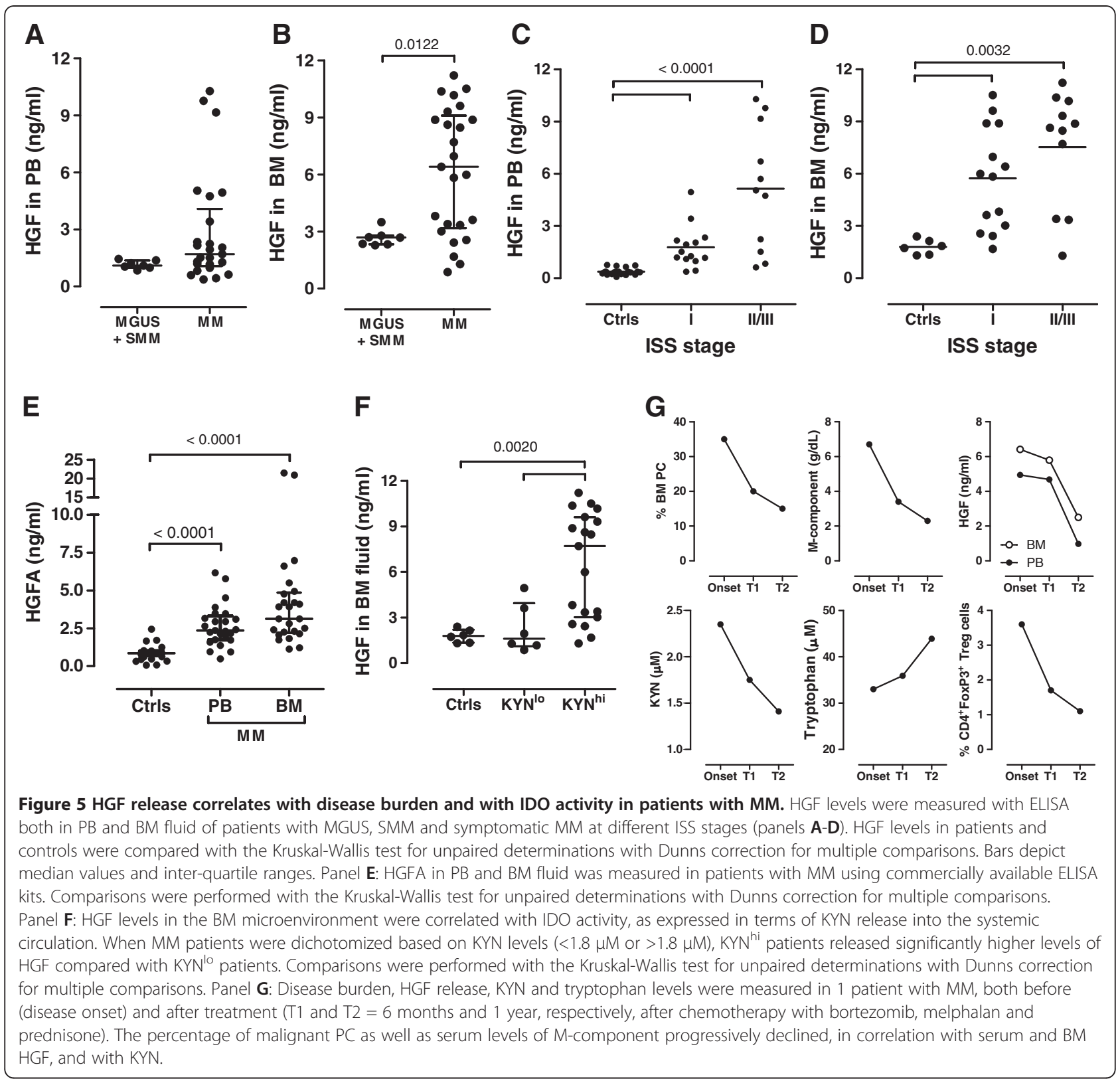

Figure $6 D$ also illustrates that pre-treatment of U266 and MOLP-8 MM cells with SU11274, a MET inhibitor, antagonized both baseline and HGF-stimulated activation of AKT. The STAT3 pathway has been implicated in immune suppressive circuits [39]. In addition, HGF can induce STAT3 phosphorylation and STAT3, in turn, interacts with MET, both directly and indirectly [40]. As shown in Figure 7A, WP1066, a potent STAT3 inhibitor, down-regulated STAT3 phosphorylation as well as IDO protein expression in MOLP-8 MM cells, but not in U266 MM cells, suggesting that HGF may be implicated in IDO regulation through multiple signaling pathways, at least in some MM cases. Finally, we focused our studies on TDO expression and activity in MM cells.
Figure $7 B$ shows that TDO protein levels were low in MM cells compared with glioma cells and primary rat hepatocytes. At variance with $1 \mathrm{MT}, 680 \mathrm{C} 91$, a selective and potent TDO inhibitor, failed to revert the increased KYN/tryptophan ratio in supernatants of MM cells (Figure 7C), suggesting that KYN production by MM cells was mainly accounted for by IDO1 activity.

\section{Discussion}

MM is a malignant PC disorder with a unique ability to subvert and/or escape immune responses. The interactions of MM cells with the BM microenvironment, either directly through inter-cellular adhesion or indirectly through the effects of growth factors, activate a variety 


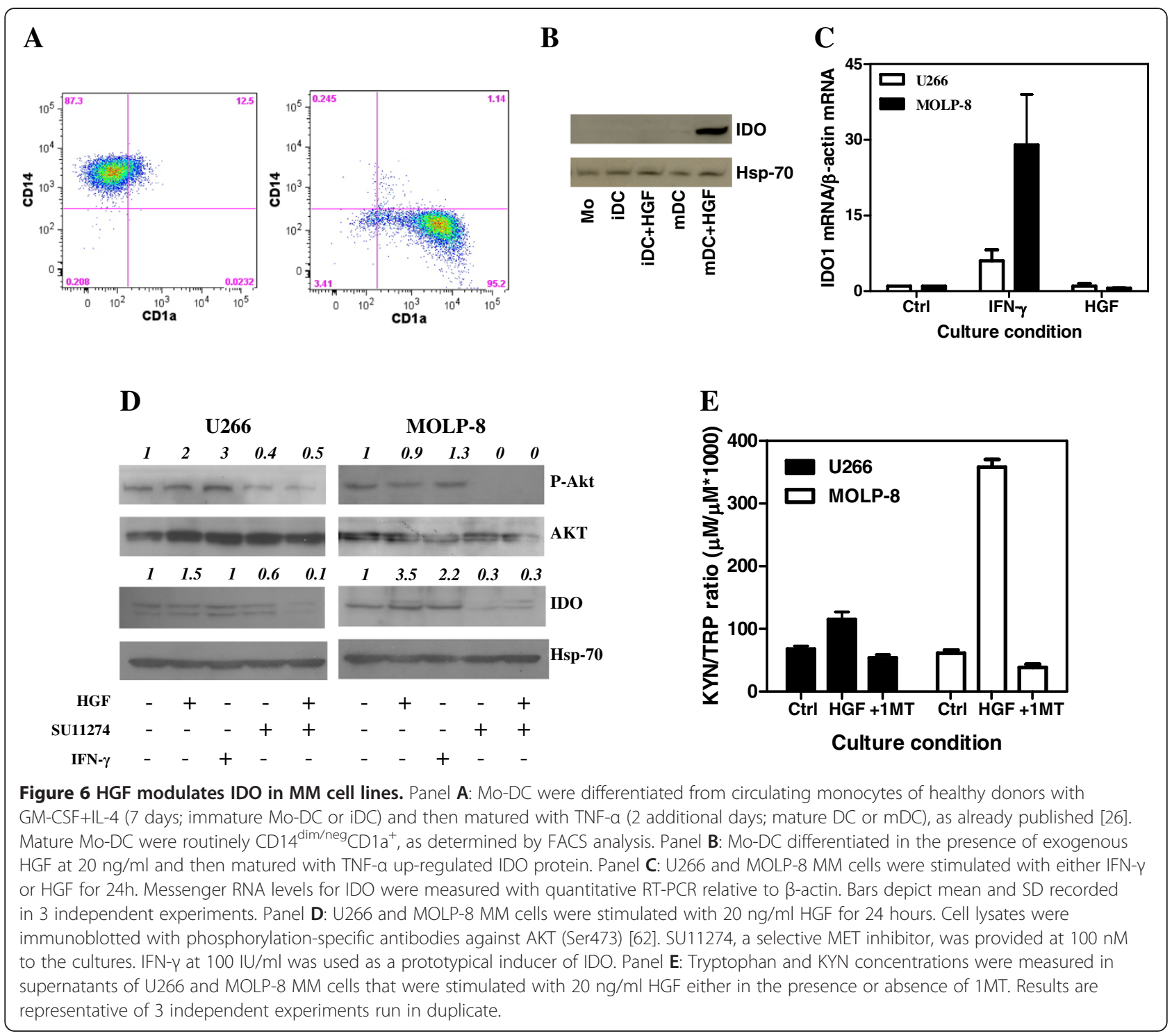

of signaling cascades [22]. In this respect, HGF released by both MM cells and BMSC is rapidly emerging as a potential target for treatment both in MM and in B-cell lymphomas [41]. Importantly, MM should be amenable to therapies aimed at restoring anti-tumor immunity, since MM cells are sensitive to immune attack in the form of graft-versus-myeloma effect [42]. A large majority of human tumors, including prostate, pancreatic and colorectal carcinomas, express IDO in a constitutive manner [43]. IFN- $\gamma$ is a prototypical IDO1-inducing cytokine in solid tumor cell lines, but not in cells of either lymphoid or myeloid origin, such as MM [44] and myeloid leukemia cells $[45,46]$. Our study evaluated the expression and function of IDO1 in human MM samples. In approximately $75 \%$ of unselected patients with symptomatic MM, IDO1 activation was reflected by the increase of serum KYN, the end-product of tryptophan breakdown by IDO. KYN levels were particularly elevated within the immune suppressive BM microenvironment of patients with ISS stage II/III myeloma disease. In the majority of MM patients, malignant PC cells were identified as a major source of IDO1 expression by Western blotting and flow cytometry. In agreement with previously published results [36], patient-derived BMSC were exquisitely sensitive to IFN- $\gamma$ challenge, as shown by the robust KYN production and concomitant tryptophan depletion in culture supernatants. This observation has two potential implications. First, IFN- $\gamma$ may not be the primary cytokine stimulus driving IDO expression in MM. Second, the IDO- BMSC may start expressing IDO when exposed to an inflammatory milieu enriched in IFN- $\gamma$, implying that the immune resistance mechanisms centered on IDO could be exploited in vivo both by the myeloma cells and by microenvironmental cell types, 


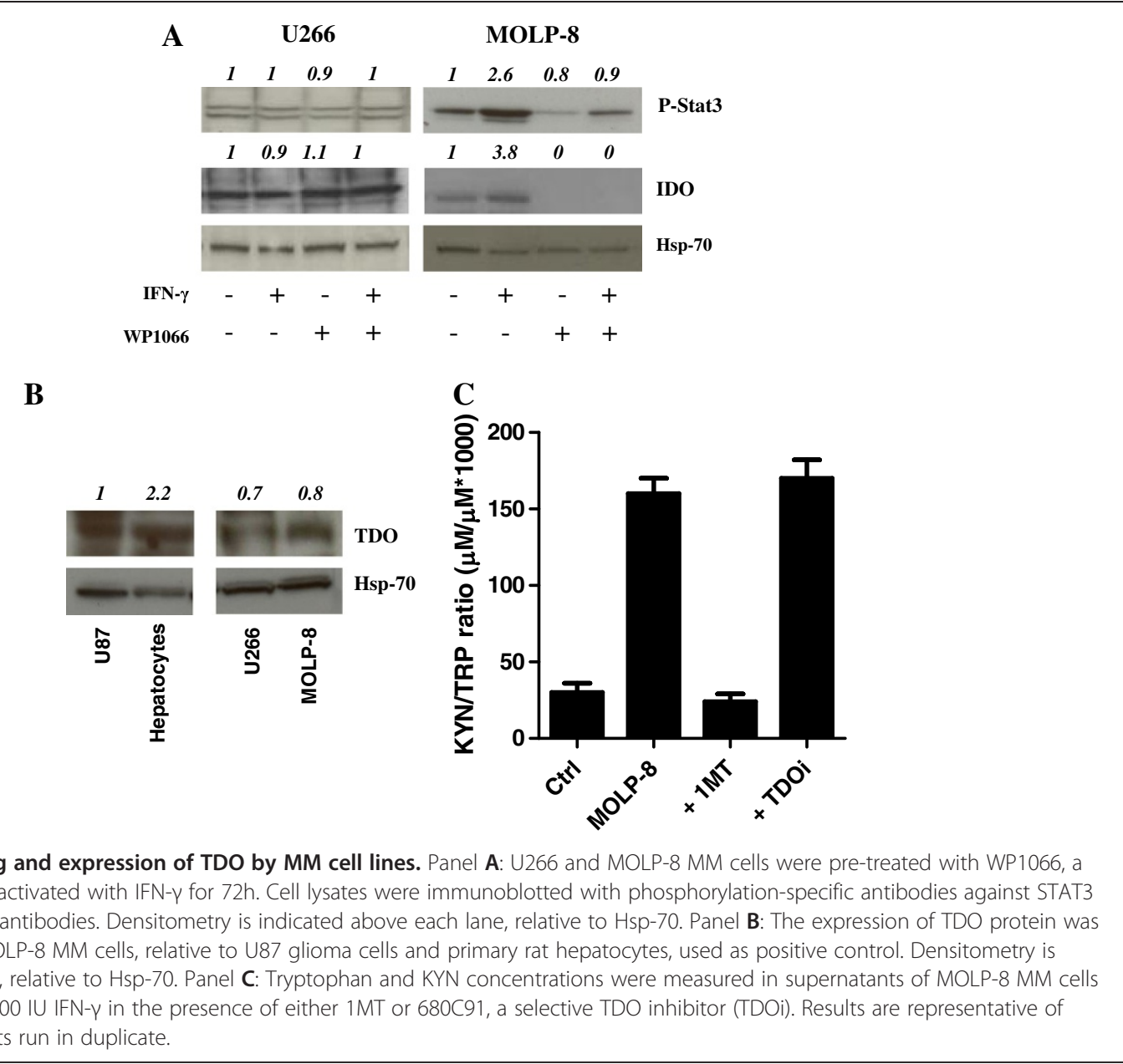

such as BMSC. Notably, IFN- $\gamma$-challenged BMSC isolated from 5 patients with MM induced IDO-dependent tryptophan deprivation, leading to MM cell apoptosis and inhibited in vitro growth [36]. It is also conceivable that microenvironmental cell types other than malignant PC may be endowed with IDO activity. In this respect, BM-resident $\mathrm{CD} 14^{+}$monocytes and BDCA- $4^{+}$plasmacytoid DC from MM patients express readily detectable levels of IDO protein (Rutella S, unpublished observations, 2012). It remains to be determined whether other accessory cells partake in IDO-driven immune suppressive circuits in MM. In this respect, activation of the KYN pathway has been reported in patients with autoimmune diseases, such as rheumatoid arthritis, systemic lupus erythematosus and systemic sclerosis, likely as a result of IDO1 expression by non-hematopoietic cell types, such as fibroblasts, epithelial cells and vascular endothelial cells $[47,48]$.

Conflicting reports have been published on the frequency of FoxP3-expressing Treg cells in patients with MGUS and MM, with studies showing either a decrease [49] or an increase of Treg cells [50]. In our cohort of
MM patients, Treg cells were over-represented both in $\mathrm{PB}$ and $\mathrm{BM}$, suggesting that Treg cells may mediate immune escape also in the BM microenvironment. Importantly, the in vivo expansion of bona fide Treg cells was more pronounced in patients with ISS stage II/III disease and correlated with both IDO1 expression in BM PC and enzyme activity, i.e., serum KYN levels. The NYESO-1 cancer/testis antigen is frequently over-expressed in MM, being a potential target for immunotherapy [51]. The percentage of NY-ESO-1-specific $\mathrm{CD}^{+} \mathrm{T}$ cells was significantly lower in $\mathrm{KYN}^{\mathrm{hi}} \mathrm{MM}$ patients and was negatively correlated with Treg-cell expansion, implying that IDO1 activity may affect the anti-myeloma immune response either directly or indirectly, through the Treg compartment. Co-cultures of allogeneic $\mathrm{T}$ cells with IDO-expressing MM cells indicated that Treg-cell expansion was mediated by IDO, as it could be inhibited, albeit not completely, by the provision of the racemic mixture D,L-1MT. We consistently observed a $\sim 50 \%$ reduction of Treg conversion by the $\mathrm{IDO}^{+}$myeloma cells, both in the presence of D,L-1MT and in the presence of the racemer L-1MT (data not shown). This may indicate 
that other mechanisms of immune subversion by MM, in addition to IDO1 expression, are operational or that 1MT-mediated inhibition of IDO1 was itself incomplete. The FoxP3-expressing Treg cells that emerged from the $\mathrm{MM} / \mathrm{T}$-cell co-cultures restrained allogeneic T-cell proliferation, suggesting that they were functional. In vitro, MM cells favored the differentiation of both FoxP3 ${ }^{\text {lo }}$ and FoxP3 ${ }^{\text {hi }}$ Treg cells. It has been reported that 'naive' Treg cells are characterized by their low levels of intracellular FoxP3 [52], whereas 'effector' Treg cells express a Fox$\mathrm{P} 3{ }^{\text {hi }}$ phenotype [53]. It is tempting to speculate that MM cells may deliver signals for initiating the expansion of both naïve Treg cells in a resting state and activated functionally differentiated effector Treg cells [54]. Furthermore, $\mathrm{CD}_{4}^{+} \mathrm{T}$ cells primed with $\mathrm{IDO}^{+} \mathrm{MM}$ cells acquired a IFN- $\gamma^{\text {dim } I L-2}{ }^{\text {dim }} \mathrm{IL}-4^{+}$IL- $10^{+}$cytokine secretion profile, consistent with type 1 Treg cells $(\operatorname{Tr} 1) / \mathrm{Th} 2$ cells. Other reports have also attributed to MM cell lines, such as U266 and RPMI-8226 cells, and to fresh MM cells the ability to down-regulate IFN- $\gamma$ release by both un-activated and activated $\mathrm{T}$ lymphocytes [55]. Also, previous studies documented the capacity of myeloma cells to induce Tr1/Th2 cytokine production by $\mathrm{T}$ cells [56]. In our co-culture system, 1MT partially reverted the inhibition of Th1 cytokine production, suggesting that IDO-expressing MM cells may impinge both on Treg responses and on the Th1/Th2 balance [57].

Our interest in HGF as a candidate stimulus driving IDO1 expression in MM stems from studies underpinning the role of HGF in myeloma pathogenesis and from our previous report on the ability of HGF to induce IDO1 in human DC [26]. In our cohort of MM patients, HGF was over-expressed both in PB and BM, being particularly elevated in patients with ISS stage II/III MM. In addition, serial measurements of disease burden, HGF levels and KYN-to-tryptophan ratio in $1 \mathrm{MM}$ patient showed that IDO1 activity decreased concomitantly with the reduction of both HGF release and PC infiltration in the BM microenvironment. It should be noted that, although HGF levels were collectively higher in $\mathrm{KYN}^{\text {hi }}$ compared with $\mathrm{KYN}^{\mathrm{lo}} \mathrm{MM}$ patients, a subgroup of 11 $\mathrm{KYN}^{\text {hi }} \mathrm{MM}$ patients were characterized by remarkably heightened HGF levels. However, their clinical and biological characteristics were not significantly different from those of the other MM patients herein analyzed, including the prevalence of unfavorable cytogenetics, such as $\operatorname{del}(13 \mathrm{q})$ and $t(4 ; 14)$ [58], the magnitude of BM infiltration with malignant $\mathrm{PC}$ at diagnosis or the ISS stage. The small number of patients, however, precluded any sensible conclusion on the impact of high IDO activity on overall survival, an issue that could be addressed by studies with larger cohorts of MM patients. Recently, a tumoral immune resistance mechanism centered on TDO has been described $[5,14]$. In our study,
MM cell lines expressed low levels of TDO compared with glioma cell lines and with primary rat hepatocytes. The provision of a selective TDO inhibitor to MM cells did not affect KYN production nor tryptophan consumption, suggesting that TDO is unlikely to play a major role in tryptophan breakdown by MM cells. The HGF/MET pathway is an emerging target for the treatment of MM, B-cell lymphomas and solid tumors $[59,60]$. MET signaling is mainly mediated by the ERKMAPK and PI3K-AKT pathways. However, several types of cooperation and crosstalk between MET and other signaling systems, such as TGF- $\beta$, WNT and others, have been unveiled in human cancer [61,62]. We confirmed that HGF is a powerful inducer of IDO in MoDC $[26,63]$ and extended this observation to show that HGF may be implicated in the regulation of IDO expression also in MM cells. In support of this statement, the provision of a MET kinase inhibitor to both U266 and MOLP-8 MM cells translated into a remarkable downregulation of IDO protein, in correlation with inhibited AKT phosphorylation. It should be pointed out that other signaling pathways, including those centered on STAT3 [64], may be operational in MM cells. This is supported by our observation that WP1066, a potent STAT3 inhibitor, abrogated IDO expression in MOLP-8 cells, either constitutive or induced by IFN- $\gamma$. Theoretically, the interaction between HGF and its receptor can be blocked by antagonists of either HGF or MET [65]. NK4, a truncated splice variant of HGF corresponding to the $\alpha$ chain of HGF, competitively antagonizes HGF and inhibits MM growth both in vitro and in vivo [66]. Intriguingly, NK4 in combination with DC vaccination inhibited the growth of experimental solid tumors, promoted tumor antigen-specific secretion of IFN- $\gamma$ by $\mathrm{CD}^{+} \mathrm{T}$ cells and elicited MHC class I-restricted CTL activity against the parental tumor cells [67]. This study strongly suggests that HGF antagonism may break immune tolerance in tumor-bearing hosts.

\section{Conclusions}

In conclusion, we provide evidence that IDO1 is expressed and has functional activity in the majority of patients with MM. Ex vivo studies point to HGF as one cytokine stimulus mediating IDO1 induction in MM. It remains to be determined whether targeting the HGF/ MET axis in MM and other HGF-expressing cancers will interfere with the tumor-induced immune dysfunction through the inhibition of IDO activity.

\section{Additional files}

Additional file 1: Gating strategy for Treg enumeration. The frequency of bona fide Treg cells was measured by multi-parameter flow cytometry in patients with MM. Representative experiments in MM 
patients with high and low KYN levels are shown. Markers were set according to the proper isotypic control. The percentage of cells staining positively for each antigen is indicated.

Additional file 2: Expression of NY-ESO-1 protein by MM cells and measurement of MM cell proliferation. The expression of NY-ESO-1 was investigated by Western blotting relative to the GAPDH housekeeping protein (panel A). U937 monocytic leukemia cells and U266 MM cells served as negative and positive control for NY-ESO-1 expression, respectively. Densitometry was used to qualitatively detect changes in protein expression. Panel B: U266 MM cells were pre-loaded with CFSE and then cultured in complete medium for 72 hours. CFSE dilution was detected by flow cytometry. Unlabeled U266 MM cells are shown as control.

Additional file 3: Intracellular cytokine staining and measurement of TGF- $\beta /$ IL-10 in MM patients. Panel A: HiCK-1 and HiCK-2 Cytokine Positive Control Cells were used in preliminary experiments to optimize intracellular cytokine staining. Markers were set according to the proper isotypic controls. Panel B: PB and BM samples from 19 patients with MM were used to quantify TGF- $\beta$ and IL-10 by ELISA.

\section{Competing interests}

The authors have no competing interests.

\section{Authors' contributions}

$G B, A M, D N, A P, L N, V F, R D C, M C, F L, G S$ and SR performed the laboratory work for this study. LDR, IM, AR, MG and AP recruited the patients. FL also provided intellectual input. SR conceived of the study, participated in its design and coordination and drafted the manuscript. All authors read and approved the final manuscript.

\section{Acknowledgements}

This study was funded by an Investigator Grant (\#8556) from Associazione Italiana per la Ricerca sul Cancro (AIRC) to SR.

\section{Author details}

'Department of Gynecology, Catholic University Med. School, Rome, Italy. ${ }^{2}$ Department of Pediatric Hematology/Oncology, IRCCS Bambino Gesù Children's Hospital, Rome, Italy. ${ }^{3}$ Department of Hematology, Azienda Ospedaliera "S. Camillo-Forlanini", Rome, Italy. ${ }^{4}$ Department of Medicine, Hemostasis Research Centre, Catholic University Med. School, Rome, Italy. ${ }^{5}$ Myeloma Unit, Division of Hematology, University of Turin, AOU S. Giovanni Battista, Turin, Italy. ${ }^{6}$ Institute of Hematology and Medical Oncology "L.\&A. Seràgnoli", University of Bologna, Bologna, Italy. "University of Pavia, Pavia, Italy.

Received: 9 July 2012 Accepted: 3 December 2012

Published: 11 December 2012

\section{References}

1. Hanahan D, Weinberg RA: Hallmarks of cancer: the next generation. Cell 2011, 144:646-674

2. Curti A, Trabanelli S, Onofri C, Aluigi M, Salvestrini V, Ocadlikova D, Evangelisti C, Rutella S, De Cristofaro R, Ottaviani $E$, et al: Indoleamine 2,3-dioxygenase-expressing leukemic dendritic cells impair a leukemia-specific immune response by inducing potent $\mathrm{T}$ regulatory cells. Haematologica 2010, 95:2022-2030.

3. Vence L, Palucka AK, Fay JW, Ito T, Liu YJ, Banchereau J, Ueno H: Circulating tumor antigen-specific regulatory $T$ cells in patients with metastatic melanoma. Proc Natl Acad Sci USA 2007, 104:20884-20889.

4. Takikawa O, Yoshida R, Kido R, Hayaishi O: Tryptophan degradation in mice initiated by indoleamine 2,3-dioxygenase. J Biol Chem 1986, 261:3648-3653.

5. Pilotte L, Larrieu P, Stroobant V, Colau D, Dolusic E, Frederick R, De Plaen E, Uyttenhove C, Wouters J, Masereel B, Van den Eynde BJ: Reversal of tumoral immune resistance by inhibition of tryptophan 2,3-dioxygenase. Proc Natl Acad Sci USA 2012, 109:2497-2502.

6. Munn DH, Sharma MD, Lee JR, Jhaver KG, Johnson TS, Keskin DB, Marshall B, Chandler P, Antonia SJ, Burgess R, et al: Potential regulatory function of human dendritic cells expressing indoleamine 2,3-dioxygenase. Science 2002, 297:1867-1870.
7. Curti A, Aluigi M, Pandolfi S, Ferri E, Isidori A, Salvestrini V, Durelli I, Horenstein AL, Fiore F, Massaia M, et al: Acute myeloid leukemia cells constitutively express the immunoregulatory enzyme indoleamine 2,3-dioxygenase. Leukemia 2007, 21:353-355.

8. lachininoto MG, Nuzzolo ER, Di Maggio A, Bonanno G, Mariotti A, Procoli A, Corallo M, Leone G, De Cristofaro R, Rutella S: COX-2 inhibition suppresses the interferon- $\gamma$-induced expression of indoleamine 2,3-dioxygenase (IDO) in human leukemia cell lines. Blood 2008, 112:1623A.

9. Brandacher G, Perathoner A, Ladurner R, Schneeberger S, Obrist P, Winkler C, Werner ER, Werner-Felmayer G, Weiss HG, Gobel G, et al: Prognostic value of indoleamine 2,3-dioxygenase expression in colorectal cancer: effect on tumor-infiltrating T cells. Clin Cancer Res 2006, 12:1144-1151.

10. Prendergast GC, Metz R, Muller AJ: IDO recruits Tregs in melanoma. Cell Cycle 2009, 8:1818-1819.

11. Takao M, Okamoto A, Nikaido T, Urashima M, Takakura S, Saito M, Okamoto S, Takikawa O, Sasaki H, Yasuda M, et al: Increased synthesis of indoleamine-2,3-dioxygenase protein is positively associated with impaired survival in patients with serous-type, but not with other types of, ovarian cancer. Oncol Rep 2007, 17:1333-1339.

12. Munn DH, Sharma MD, Baban B, Harding HP, Zhang Y, Ron D, Mellor AL: GCN2 kinase in T cells mediates proliferative arrest and anergy induction in response to indoleamine 2,3-dioxygenase. Immunity 2005, 22:633-642.

13. Abrams BL, Holloway PH: Role of the surface in luminescent processes. Chem Rev 2004, 104:5783-5801.

14. Opitz CA, Litzenburger UM, Sahm F, Ott M, Tritschler I, Trump S, Schumacher $T$, Jestaedt $L$, Schrenk D, Weller $M$, et al: An endogenous tumour-promoting ligand of the human aryl hydrocarbon receptor. Nature 2011, 478:197-203.

15. Palumbo A, Anderson K: Multiple myeloma. N Engl J Med 2011, 364:1046-1060.

16. Kumar S, Flinn I, Richardson PG, Hari P, Callander N, Noga SJ, Stewart AK, Turturro F, Rifkin R, Wolf J, et al: Randomized, multicenter, phase 2 study (EVOLUTION) of combinations of bortezomib, dexamethasone, cyclophosphamide, and lenalidomide in previously untreated multiple myeloma. Blood 2012, 119:4375-4382.

17. Ludwig H, Durie BG, McCarthy P, Palumbo A, San Miguel J, Barlogie B, Morgan G, Sonneveld P, Spencer A, Andersen KC, et al: IMWG consensus on maintenance therapy in multiple myeloma. Blood 2012, 119:3003-3015.

18. Bruno B, Rotta M, Patriarca F, Mordini N, Allione B, Carnevale-Schianca F, Giaccone L, Sorasio R, Omede P, Baldi I, et al: A comparison of allografting with autografting for newly diagnosed myeloma. N Engl J Med 2007, 356:1110-1120.

19. Ratta M, Fagnoni F, Curti A, Vescovini R, Sansoni P, Oliviero B, Fogli M, Ferri E, Della Cuna GR, Tura S, et al: Dendritic cells are functionally defective in multiple myeloma: the role of interleukin-6. Blood 2002, 100:230-237.

20. Feyler $S$, von Lilienfeld-Toal M, Jarmin S, Marles $L$, Rawstron A, Ashcroft AJ, Owen RG, Selby PJ, Cook G: CD4 ${ }^{+} \mathrm{CD} 25^{+} \mathrm{FoxP}^{+}$regulatory $\mathrm{T}$ cells are increased whilst $\mathrm{CD}^{+} \mathrm{CD} 4^{-} \mathrm{CD} 8^{-} \mathrm{a} \mathrm{TCR}^{+}$double negative $\mathrm{T}$ cells are decreased in the peripheral blood of patients with multiple myeloma which correlates with disease burden. Br J Haematol 2009, 144:686-695.

21. Chauhan D, Singh AV, Brahmandam M, Carrasco R, Bandi M, Hideshima T, Bianchi G, Podar K, Tai YT, Mitsiades C, et al: Functional interaction of plasmacytoid dendritic cells with multiple myeloma cells: a therapeutic target. Cancer Cell 2009, 16:309-323.

22. Hideshima T, Mitsiades C, Tonon G, Richardson PG, Anderson KC: Understanding multiple myeloma pathogenesis in the bone marrow to identify new therapeutic targets. Nat Rev Cancer 2007, 7:585-598.

23. Seidel C, Borset M, Turesson I, Abildgaard N, Sundan A, Waage A: Elevated serum concentrations of hepatocyte growth factor in patients with multiple myeloma. The Nordic Myeloma Study Group. Blood 1998, 91:806-812

24. Okunishi K, Dohi M, Fujio K, Nakagome K, Tabata Y, Okasora T, Seki M, Shibuya M, Imamura M, Harada H, et al: Hepatocyte growth factor significantly suppresses collagen-induced arthritis in mice. J Immunol 2007, 179:5504-5513.

25. Kuroiwa T, Kakishita E, Hamano T, Kataoka Y, Seto Y, Iwata N, Kaneda Y, Matsumoto K, Nakamura T, Ueki T, et al: Hepatocyte growth factor 
ameliorates acute graft-versus-host disease and promotes hematopoietic function. J Clin Invest 2001, 107:1365-1373.

26. Rutella S, Bonanno G, Procoli A, Mariotti A, de Ritis DG, Curti A, Danese S, Pessina G, Pandolfi S, Natoni F, et al: Hepatocyte growth factor favors monocyte differentiation into regulatory interleukin (IL) $-10^{++} \mathrm{IL}-12^{\text {low/neg }}$ accessory cells with dendritic-cell features. Blood 2006, 108:218-227.

27. Tjin EP, Derksen PW, Kataoka H, Spaargaren M, Pals ST: Multiple myeloma cells catalyze hepatocyte growth factor (HGF) activation by secreting the serine protease HGF-activator. Blood 2004, 104:2172-2175.

28. Seidel C, Borset M, Hjertner O, Cao D, Abildgaard N, Hjorth-Hansen H, Sanderson RD, Waage A, Sundan A: High levels of soluble syndecan-1 in myeloma-derived bone marrow: modulation of hepatocyte growth factor activity. Blood 2000, 96:3139-3146.

29. Seidel C, Lenhoff S, Brabrand S, Anderson G, Standal T, Lanng-Nielsen J, Turesson I, Borset M, Waage A: Hepatocyte growth factor in myeloma patients treated with high-dose chemotherapy. Br I Haematol 2002, 119:672-676.

30. Berthou S, Aebersold DM, Schmidt LS, Stroka D, Heigl C, Streit B, Stalder D, Gruber G, Liang C, Howlett AR, et al: The Met kinase inhibitor SU11274 exhibits a selective inhibition pattern toward different receptor mutated variants. Oncogene 2004, 23:5387-5393.

31. Greipp PR, San Miguel J, Durie BG, Crowley JJ, Barlogie B, Blade J, Boccadoro M, Child JA, Avet-Loiseau H, Kyle RA, et al: International staging system for multiple myeloma. J Clin Oncol 2005, 23:3412-3420.

32. Munshi NC, Anderson KC, Bergsagel PL, Shaughnessy J, Palumbo A, Durie B, Fonseca R, Stewart AK, Harousseau JL, Dimopoulos M, et al: Consensus recommendations for risk stratification in multiple myeloma: report of the International Myeloma Workshop Consensus Panel 2. Blood 2011, 117:4696-4700.

33. Rutella S, Bonanno G, Pierelli L, Mariotti A, Capoluongo E, Contemi AM, Ameglio F, Curti A, De Ritis DG, Voso MT, et al: Granulocyte colonystimulating factor promotes the generation of regulatory DC through induction of IL-10 and IFN-a. Eur J Immunol 2004, 34:1291-1302

34. Rutella S, Pierelli L, Bonanno G, Sica S, Ameglio F, Capoluongo E, Mariotti A, Scambia G, D'Onofrio G, Leone G: Role for granulocyte colony-stimulating factor in the generation of human T regulatory type 1 cells. Blood 2002, 100:2562-2571.

35. Rutella S, Pierelli L, Rumi C, Bonanno G, Marone M, Sica S, Capoluongo E, Ameglio F, Scambia G, Leone G: T-cell apoptosis induced by granulocyte colony-stimulating factor is associated with retinoblastoma protein phosphorylation and reduced expression of cyclin-dependent kinase inhibitors. Exp Hematol 2001, 29:401-415.

36. Pfeifer S, Schreder M, Bolomsky A, Graffi S, Fuchs D, Sahota SS, Ludwig H, Zojer N: Induction of indoleamine-2,3 dioxygenase in bone marrow stromal cells inhibits myeloma cell growth. J Cancer Res Clin Oncol 2012, 138:1821-1830.

37. Brown RD, Pope B, Murray A, Esdale W, Sze DM, Gibson J, Ho PJ, Hart D, Joshua D: Dendritic cells from patients with myeloma are numerically normal but functionally defective as they fail to up-regulate CD80 (B7-1) expression after huCD40LT stimulation because of inhibition by transforming growth factor- $\beta 1$ and interleukin-10. Blood 2001, 98:2992-2998

38. Chauhan D, Uchiyama H, Akbarali Y, Urashima M, Yamamoto K, Libermann TA, Anderson KC: Multiple myeloma cell adhesion-induced interleukin- 6 expression in bone marrow stromal cells involves activation of NF-kB. Blood 1996, 87:1104-1112.

39. Kanterman J, Sade-Feldman M, Baniyash M: New insights into chronic inflammation-induced immunosuppression. Semin Cancer Biol 2012, 22:307-318

40. Boccaccio C, Ando M, Tamagnone L, Bardelli A, Michieli P, Battistini C, Comoglio PM: Induction of epithelial tubules by growth factor HGF depends on the STAT pathway. Nature 1998, 391:285-288.

41. Teofili L, Di Febo AL, Pierconti F, Maggiano N, Bendandi M, Rutella S, Cingolani A, Di Renzo N, Musto P, Pileri S, et al: Expression of the c-met proto-oncogene and its ligand, hepatocyte growth factor, in Hodgkin disease. Blood 2001, 97:1063-1069.

42. Kroger N: Mini-Midi-Maxi? How to harness the graft-versus-myeloma effect and target molecular remission after allogeneic stem cell transplantation. Leukemia 2007, 21:1851-1858.
43. Uyttenhove C, Pilotte L, Theate I, Stroobant V, Colau D, Parmentier N, Boon T, Van den Eynde BJ: Evidence for a tumoral immune resistance mechanism based on tryptophan degradation by indoleamine 2,3-dioxygenase. Nat Med 2003, 9:1269-1274.

44. Takikawa O, Kuroiwa T, Yamazaki F, Kido R: Mechanism of interferon- $\gamma$ action. Characterization of indoleamine 2,3-dioxygenase in cultured human cells induced by interferon- $\gamma$ and evaluation of the enzyme-mediated tryptophan degradation in its anticellular activity. J Biol Chem 1988, 263:2041-2048.

45. Ozaki Y, Edelstein MP, Duch DS: Induction of indoleamine 2,3dioxygenase: a mechanism of the antitumor activity of interferon $\gamma$. Proc Natl Acad Sci USA 1988, 85:1242-1246.

46. Curti A, Trabanelli S, Salvestrini V, Baccarani M, Lemoli RM: The role of indoleamine 2,3-dioxygenase in the induction of immune tolerance: Focus on hematology. Blood 2009, 113:2394-2401.

47. Filippini P, Del Papa N, Sambataro D, Del Bufalo A, Locatelli F, Rutella S. Emerging concepts on inhibitors of indoleamine 2,3-dioxygenase in rheumatic diseases. Curr Med Chem 2012, 19:5381-5393.

48. Munn DH, Mellor AL: Indoleamine 2,3 dioxygenase and metabolic control of immune responses. Trends Immunol 2012, doi:10.1016/j.it.2012.10.001.

49. Prabhala RH, Neri P, Bae JE, Tassone P, Shammas MA, Allam CK, Daley JF, Chauhan D, Blanchard E, Thatte HS, et al: Dysfunctional T regulatory cells in multiple myeloma. Blood 2006, 107:301-304.

50. Beyer M, Kochanek M, Giese T, Endl E, Weihrauch MR, Knolle PA, Classen S, Schultze JL: In vivo peripheral expansion of naive $\mathrm{CD}^{+} \mathrm{CD} 25^{\text {high }} \mathrm{FoxP}^{+}$ regulatory T cells in patients with multiple myeloma. Blood 2006, 107:3940-3949.

51. Atanackovic D, Arfsten J, Cao Y, Gnjatic S, Schnieders F, Bartels K, Schilling G, Faltz C, Wolschke C, Dierlamm J, et al: Cancer-testis antigens are commonly expressed in multiple myeloma and induce systemic immunity following allogeneic stem cell transplantation. Blood 2007 109:1103-1112.

52. Valmori D, Merlo A, Souleimanian NE, Hesdorffer CS, Ayyoub M: A peripheral circulating compartment of natural naive CD4 Tregs. J Clin Invest 2005, 115:1953-1962.

53. Baecher-Allan C, Brown JA, Freeman GJ, Hafler DA: CD4 ${ }^{+} \mathrm{CD} 25^{\text {high }}$ regulatory cells in human peripheral blood. I Immunol 2001, 167:1245-1253.

54. Sakaguchi S, Miyara M, Costantino CM, Hafler DA: FOXP3 ${ }^{+}$regulatory T cells in the human immune system. Nat Rev Immunol 2010, 10:490-500.

55. Giuliani N, Colla S, Sala R, Moroni M, Lazzaretti M, La Monica S, Bonomini S, Hojden M, Sammarelli G, Barille S, et al: Human myeloma cells stimulate the receptor activator of nuclear factor-KB ligand (RANKL) in T lymphocytes: a potential role in multiple myeloma bone disease. Blood 2002, 100:4615-4621.

56. Fiore F, Nuschak B, Peola S, Mariani S, Muraro M, Foglietta M, Coscia M, Bruno B, Boccadoro M, Massaia M: Exposure to myeloma cell lysates affects the immune competence of dendritic cells and favors the induction of Tr1-like regulatory T cells. Eur J Immunol 2005, 35:1155-1163.

57. Xu H, Oriss TB, Fei M, Henry AC, Melgert BN, Chen L, Mellor AL, Munn DH, Irvin CG, Ray P, Ray A: Indoleamine 2,3-dioxygenase in lung dendritic cells promotes Th2 responses and allergic inflammation. Proc Natl Acad Sci USA 2008, 105:6690-6695.

58. Kapoor P, Kumar S, Fonseca R, Lacy MQ, Witzig TE, Hayman SR, Dispenzieri A, Buadi F, Bergsagel PL, Gertz MA, et al: Impact of risk stratification on outcome among patients with multiple myeloma receiving initial therapy with lenalidomide and dexamethasone. Blood 2009, 114:518-521.

59. Tjin EP, Groen RW, Vogelzang I, Derksen PW, Klok MD, Meijer HP, van Eeden S, Pals ST, Spaargaren M: Functional analysis of HGF/MET signaling and aberrant HGF-activator expression in diffuse large B-cell lymphoma. Blood 2006, 107:760-768.

60. Peters $\mathrm{S}$, Adjei AA: MET: a promising anticancer therapeutic target. Nat Rev Clin Oncol 2012, 9:314-326.

61. Gherardi E, Birchmeier W, Birchmeier C, Woude GV: Targeting MET in cancer: rationale and progress. Nat Rev Cancer 2012, 12:89-103.

62. Comoglio PM, Giordano S, Trusolino L: Drug development of MET inhibitors: targeting oncogene addiction and expedience. Nat Rev Drug Discov 2008, 7:504-516.

63. Rutella S, Danese S, Leone G: Tolerogenic dendritic cells: cytokine modulation comes of age. Blood 2006, 108:1435-1440 
64. Syed ZA, Yin W, Hughes K, Gill JN, Shi R, Clifford JL: HGF/c-met/Stat3 signaling during skin tumor cell invasion: indications for a positive feedback loop. BMC Cancer 2011, 11:180.

65. Gordon MS, Sweeney CS, Mendelson DS, Eckhardt SG, Anderson A, Beaupre DM, Branstetter D, Burgess TL, Coxon A, Deng H, et al: Safety, pharmacokinetics, and pharmacodynamics of AMG 102, a fully human hepatocyte growth factor-neutralizing monoclonal antibody, in a first-in-human study of patients with advanced solid tumors. Clin Cancer Res 2010, 16:699-710.

66. Du W, Hattori Y, Yamada T, Matsumoto K, Nakamura T, Sagawa M, Otsuki T, Niikura T, Nukiwa T, Ikeda Y: NK4, an antagonist of hepatocyte growth factor (HGF), inhibits growth of multiple myeloma cells: molecular targeting of angiogenic growth factor. Blood 2007, 109:3042-3049.

67. Kikuchi T, Maemondo M, Narumi K, Matsumoto K, Nakamura T, Nukiwa T: Tumor suppression induced by intratumor administration of adenovirus vector expressing NK4, a 4-kringle antagonist of hepatocyte growth factor, and naive dendritic cells. Blood 2002, 100:3950-3959.

doi:10.1186/1479-5876-10-247

Cite this article as: Bonanno et al:: Indoleamine 2,3-dioxygenase 1

(IDO1) activity correlates with immune system abnormalities in multiple myeloma. Journal of Translational Medicine 2012 10:247.

\section{Submit your next manuscript to BioMed Central and take full advantage of:}

- Convenient online submission

- Thorough peer review

- No space constraints or color figure charges

- Immediate publication on acceptance

- Inclusion in PubMed, CAS, Scopus and Google Scholar

- Research which is freely available for redistribution 